
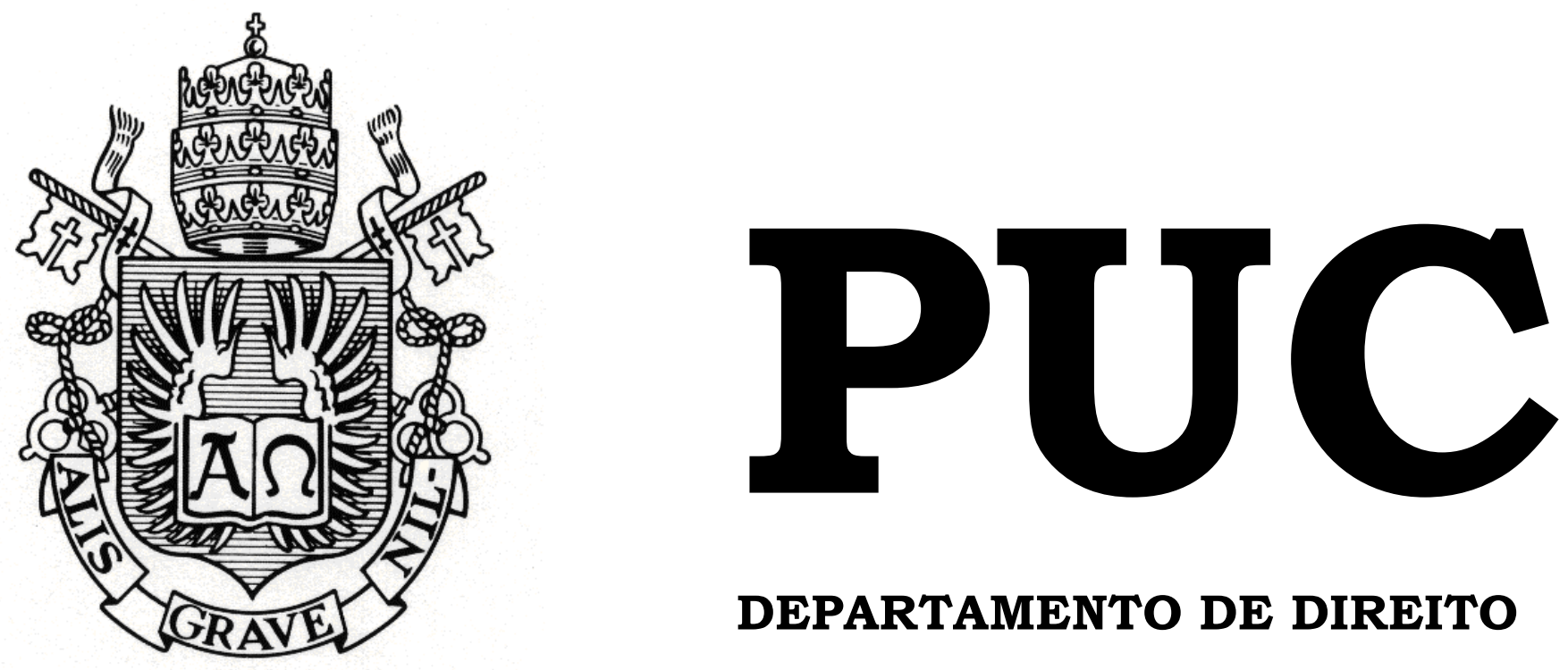

DEPARTAMENTO DE DIREITO

\title{
A CENSURA JUDICIAL À IMPRENSA NA COBERTURA DOS CASOS SUB JUDICE
}

por

PAULA STRUNCK DA SILVA PINTO

ORIENTADOR: Fábio Carvalho Leite

2010.2

PONTIFÍCIA UNIVERSIDADE CATÓLICA DO RIO DE JANEIRO RUA MARQUÊS DE SÃO VICENTE, 225 - CEP 22453-900 RIO DE JANEIRO - BRASIL 


\title{
A CENSURA JUDICIAL À IMPRENSA NA COBERTURA DOS CASOS SUB JUDICE
}

\author{
por
}

PAULA STRUNCK DA SILVA PINTO

Monografia apresentada ao Departamento de Direito da Pontifícia Universidade Católica do Rio de Janeiro (PUC-Rio) para a obtenção do Título de Bacharel em Direito.

Orientador: Fábio Carvalho Leite 


\section{AGRADECIMENTOS}

Aos meus pais, Márcio e Gisah, agradeço pelas escolhas acertadas na minha educação, que me permitiram hoje escolher eu mesma os melhores caminhos.

Ao Bruno Góes agradeço pela paciência nos momentos de aflição, pelas contribuições bibliográficas e pela visão jornalística deste trabalho, o que me permitiu entender melhor o outro polo do conflito nesta obra apresentado.

Agradeço à Joana Navega pelos interessantes debates e pelas inúmeras contribuições, sugestões e comentários dados no decorrer da elaboração deste trabalho.

Ao Professor Fábio Carvalho Leite agradeço pelas valiosas sugestões e correções.

Agradeço, ainda, à Diretoria Jurídica das Organizações Globo por ter me proporcionado não apenas o acesso à biblioteca e por ter despertado em mim o interesse pelo tema nesta monografia tratado, mas, sobretudo, a convivência com pessoas que propiciaram o estímulo decisivo para o meu crescimento profissional.

Sem essas pessoas (algumas a quem talvez não tenha mencionado expressamente), estes passos iniciais da minha vida acadêmica talvez nem mesmo tivessem sido dados.

A todos, muito obrigada. 


\section{RESUMO}

PINTO, Paula Strunck da Silva. A Censura Judicial à Imprensa na cobertura dos casos sub judice. Rio de Janeiro. 2010. 101p. Monografia de final de curso - Departamento de Direito, Pontifícia Universidade Católica do Rio de Janeiro.

Esta monografia trata da censura imposta pelo Poder Judiciário à imprensa, seja antes da publicação das notícias sobre os casos sub judice, através de decisões em caráter liminar, ou depois dessa, por meio do pagamento de indenizações a título de danos morais, cujo efeito inibidor é semelhante ao da censura prévia. Para entender os motivos de tal censura, será feita uma análise da relação entre os meios de comunicação e o Poder Judiciário, em especial da influência que a imprensa exerce sobre as decisões judiciais. Com isso, será possível avaliar se a censura judicial às notícias sobre os casos sub judice justifica-se ou não, na medida em que se pretende, com ela, evitar que a influência da mídia sobre a opinião pública e sobre os juízes e jurados prejudique a imparcialidade desses e leve à violação dos direitos da personalidade daqueles retratados em tais notícias. É o que se pretende apontar, traçando, para tanto, um estudo detalhado da proteção constitucional conferida às liberdades de expressão, imprensa, comunicação e ao direito à informação, bem como das espécies de restrições eventualmente a elas impostas, para, ao fim, analisar de forma crítica a jurisprudência brasileira sobre o tema, tentando situar e definir a tendência do Poder Judiciário do Brasil no que se refere à proteção das liberdades democráticas.

Palavras-chave: Censura a posteriori - Censura judicial - Censura prévia - Direito à Informação - Direitos da personalidade - Imparcialidade Imprensa - Influência - Jornalismo - Liberdade de expressão - Liberdade de Imprensa - Meios de comunicação - Poder Judiciário - Segredo de Justiça - sub judice. 
INTRODUÇÃO

9

1. LIBERDADES DE EXPRESSÃO, IMPRENSA, COMUNICAÇÃO E DIREITO À INFORMAÇÃO ..................... 14

1.1 Liberdade de Expressão ................................................................ 14

1.2 Conceito de imprensa e sua liberdade..................................... 17

1.3 Liberdade de Comunicação versus Liberdade de Expressão ...................................................................................... 19

1.4 Direito à informação .............................................................. 21

1.4.1 As facetas do Direito à informação..............................21

1.4.2 As acepções positiva e negativa do direito à informação .............................................................................. 22

1.4.3 Direito à difusão de notícias e direito à crítica ..........23

1.4.4 A função social do direito à informação.......................24

1.5 Breve histórico das liberdades de comunicação e expressão ...............................................................................................227

2. RESTRIÇÕES ÀS LIBERDADES DE EXPRESSÃO, IMPRENSA E COMUNICAÇÃO E DIREITO DE INFORMAR

2.1 Conceito de censura ...................................................................32

2.2 Tipos de censura......................................................................33

2.2.1 Quanto ao momento..........................................................34

2.2.1.1 A censura prévia...................................................34

2.2.1.1.1 Breves notas sobre a censura até o governo Getúlio Vargas.....................34

2.2.1.1.2 Departamento de Imprensa e propaganda: a censura na Era Vargas ......................................................... 36 
2.2.1.1.3 Censura à imprensa na Ditadura

Militar 38

2.2.1.2 A censura a posteriori........................................39

2.2.2 Quanto à forma ...................................................................43

2.2.2.1 Administrativa ................................................... 43

2.2.2.2 Judicial ......................................................................... 43

2.3 Há uma maneira melhor de restringir liberdades? .............. 45

3. A INFLUÊNCIA DOS MEIOS DE COMUNICAÇÃO SOBRE O PODER JUDICIÁRIO E OS LIMITES IMPOSTOS POR ESSE ÀQUELES ............................................................................................. 48

3.1 O jornalismo investigativo e o "denuncismo" ....................... 48

3.2 A ofensa ao princípio da presunção de inocência ................ 52

3.3 Segredo de justiça .............................................................................53

3.4 A imparcialidade dos julgadores e a influência das notícias nas decisões judiciais, em especial, as criminais ...56

3.4.1 O princípio da imparcialidade .......................................56

3.4.2 Opinião pública ....................................................................5 57

3.4.3 A influência das notícias sobre opinião pública e sobre os membros Poder Judiciário ..............................58

3.4.4 O Trial by the Media .....................................................59

3.4.5 As tentativas de evitar o prejulgamento pela mídia 60

3.5 Choque entre direitos fundamentais ......................................... 61

3.5.1 Liberdades de expressão, imprensa, comunicação e direito à informação versus direitos da personalidade.....................................................................61 61

3.5.2 Ponderação de princípios e direitos fundamentais .. 62

3.5.2.1 Critérios de ponderação ................................... 64

3.5.3 O papel do Poder Judiciário no conflito ...................... 66

4. A CENSURA JUDICIAL - PRÉVIA E A POSTERIORI - À IMPRENSA NA COBERTURA DOS CASOS SUB JUDICE .... 68 
4.1 A tendência do Poder Judiciário do Brasil ............................ 68

4.2 A motivação das decisões judiciais .................................. 69

4.3 Os casos sub judice e as decisões judiciais contra a imprensa........................................................................ 70

4.3.1 Censura judicial prévia ............................................70

4.3.1.1 Renato Mehanna Khamis versus Editora Abril S/A, UOL Universo Online Ltda., AOL Brasil Ltda., Rádio e Televisão Bandeirantes Ltda. e Valor Econômico S/A....................... 70

4.3.1.2 O caso do governador Carlos Gaguim .......... 72

4.3.1.3 Um caso paradigmático: censura ao "Estadão" 73

4.3.1.4 Rede Globo de Televisão, TV Clube e jornalista Roberto Cabrini versus Desembargador Albuquerque e família....... 77

4.3.1.5 Tribuna Popular versus Dari Pagel ............... 79

4.3.2 Cesura judicial $a$ posteriori....................................80

4.3.2.1 Jornal "Lance!" versus Wagner Tardelli de Azevedo ...........................................................81

4.3.2.2 Jornal "Tapera" versus Valério Francisco de Moraes.................................................................. 82

4.3.2.3 Jornal "O Povo" versus Maria Nilda Santos Silva e Outros 83

4.3.2.4 Fundação Universo versus Verônica Coutinho de Carvalho ....................................................... 84

4.3.2.5 Jornal "O Dia" versus Anderson dos Santos Sermud ............................................................. 85 


\section{ABREVIATURAS E SÍMBOLOS}

\begin{tabular}{|c|c|}
\hline abr. & Abril \\
\hline $\mathrm{ADPF}$ & Aguição de Descumprimento de Preceito Fundamental \\
\hline AI & Ato Institucional \\
\hline ago. & Agosto \\
\hline ANJ & Associação Nacional de Jornais \\
\hline art. & Artigo \\
\hline Cispen & Coordenadoria de Inteligência do Sistema Penitenciário \\
\hline CNJ & Conselho Nacional de Justiça \\
\hline CPDOC & $\begin{array}{l}\text { Centro de Pesquisa e Documentação de História } \\
\text { Contemporânea do Brasil }\end{array}$ \\
\hline dez. & Dezembro \\
\hline DF & Distrito Federal \\
\hline DIP & Departamento de Imprensa e Propaganda \\
\hline DU & Diário da União \\
\hline ed. & Editora \\
\hline Emerj & Escola de Magistratura do Rio de Janeiro \\
\hline fev. & Fevereiro \\
\hline FGV & Fundação Getúlio Vargas \\
\hline IBCcrim & Instituto Brasileiro de Ciências Criminais \\
\hline Ibid. & Ibidem ('mesmo autor e mesma obra') \\
\hline jul. & Julho \\
\hline jun. & Junho \\
\hline mai. & Maio \\
\hline mar. & Março \\
\hline MG & Minas Gerais \\
\hline Min. & Ministro \\
\hline $\mathrm{n}^{\mathrm{o}}$ & Número \\
\hline Op. Cit. & Opus citatum ('na obra citada') \\
\hline ONG & Organização Não-Governamental \\
\hline org. & Organizador(a) \\
\hline out. & Outubro \\
\hline p. & Página \\
\hline Pet. & Petição \\
\hline PMDB & Partido do Movimento Democrático Brasileiro \\
\hline PR & Paraná \\
\hline Rel. & Relator(a) \\
\hline Resp & Recurso Especial \\
\hline RMS & Recurso em Mandado de Segurança \\
\hline $\mathrm{R} \$$ & Reais (moeda brasileira) \\
\hline set. & Setembro \\
\hline STF & Supremo Tribunal Federal \\
\hline STJ & Superior Tribunal de Justiça \\
\hline $\mathrm{TJ} / \mathrm{CE}$ & Tribunal de Justiça do Ceará \\
\hline
\end{tabular}


TJ/DF Tribunal de Justiça do Distrito Federal

TJ/PI Tribunal de Justiça do Piauí

TJ/RJ Tribunal de Justiça do Rio de Janeiro

TJ/RS Tribunal de Justiça do Rio Grande do Sul

TJ/SP Tribunal de Justiça de São Paulo

TRE/TO Tribunal Regional Eleitoral do Tocantins

t.

Título

TV Televisão

v. Volume

Vs. Versus

$\S \quad$ Parágrafo 


\section{INTRODUÇÃO}

"Libertas omnibus rebus favorabilior est"

Diariamente os jornais noticiam casos que ainda estão sob apreciação judicial, os chamados casos sub judice, muitas vezes condenando os supostos culpados, influenciando a opinião pública, mesmo antes da condenação oficial. São também comuns as críticas jornalísticas às limitações impostas pelo Poder Judiciário à imprensa, muitas das quais se dão justamente em razão dos abusos cometidos na cobertura dos casos sub judice.

De um lado, a imprensa exalta as mazelas do Poder Judiciário, sua lentidão, a suposta manutenção, pelos juízes, da impunidade e os constantes ataques às liberdades de expressão e imprensa, além de noticiar crimes sempre se baseando na versão acusatória desses, ferindo, de acordo com alguns, os direitos da personalidade e o princípio da presunção de inocência. De outro lado, o Poder Judiciário, sob a alegação de proteção dos direitos da personalidade e de preservação do segredo de justiça e da imparcialidade dos julgadores, cerceia a livre expressão da imprensa, muitas vezes por motivos políticos ou corporativos.

Em meio a essa relação conflituosa entre os meios de comunicação e o Poder Judiciário, o presente trabalho tem como objetivo tratar da censura imposta pelo Poder Judiciário aos meios de comunicação na cobertura dos casos sub judice, seja antes da publicação das notícias que deles tratam, através de decisões em caráter liminar, ou depois dessa, por meio do pagamento de indenizações a título de danos morais, cujo efeito inibidor é semelhante ao da censura prévia.

Avaliar-se-á, nos capítulos que se seguem, se tais restrições impostas pelo Poder Judiciário são necessárias à defesa dos direitos da personalidade

\footnotetext{
1 “Em todos os casos a liberdade é mais favorável” (Brocardo Romano)
} 
e à preservação do segredo de justiça e da imparcialidade dos julgadores ou se elas violam as liberdades de expressão, imprensa, comunicação e o direito à informação, bem como a vedação constitucional de qualquer tipo de censura. Pretende-se, assim, investigar se a imprensa exagera nas reações a tais restrições ou se é o Poder Judiciário que se vale da suposta proteção aos direitos da personalidade para limitar as expressões que o prejudicam. Para isso, será necessário analisar a influência da imprensa sobre as investigações e as decisões judiciais e a relação de mútua desconfiança e de ataques recíprocos entre esses dois polos.

A análise de tal relação, a seguir realizada, será feita com base, principalmente, na cobertura feita pelos meios de comunicação e pelos jornalistas dos casos criminais sub judice, em virtude de serem esses os casos que maior atenção recebem da imprensa, justamente por serem os casos que parecem mais interessar à população.

Ao contrário do que dá a entender a leitura simples da Constituição Federal, a censura aos veículos de comunicação não deixou de existir na medida em que foram extintos os órgãos administrativos especializados em apreender e limitar publicações. Censurar nada mais é que cercear a expressão, reprovar e repreender, o que pode dar-se antes ou depois da publicação, seja administrativa ou judicialmente.

Procurar-se-á demonstrar aqui que a censura no Brasil tem hoje origem no Poder Judiciário, em especial nas primeiras instâncias desse. E que, embora as decisões que cerceiam a expressão da imprensa sejam, em regra, revertidas pelas instâncias superiores do Poder Judiciário, essas geram um efeito inibidor da expressão, de tal forma que levam à autocensura por parte dos meios de comunicação.

Por outro lado, os veículos de comunicação e os jornalistas, por vezes, exageram nas reações a certas decisões judiciais, fazendo com que a opinião pública volte-se contra o Poder Judiciário, algumas das vezes, sem 
razão. Além disso, não são raros os casos em que notícias ou críticas equivocadas ou imprecisas sobre decisões judiciais são publicadas.

Esclareça-se, desde já, que o fato de dizer que o Poder Judiciário realiza censura aos meios de comunicação não significa que no termo “censura” há qualquer juízo de valor, ou melhor, não há nessa constatação, a princípio, qualquer crítica. Dessa forma, a afirmação de que o Poder Judiciário censura a imprensa, como se verá, não significa que tal limitação não seja eventualmente necessária para conter os abusos cometidos no exercício das liberdades de expressão, de comunicação, de imprensa e do direito de informar, bem como para evitar que a cobertura da imprensa dos casos sub judice possa prejudicar a imparcialidade das investigações e dos julgamentos. Portanto, deve-se entender por censura apenas restrição, limite, muitas vezes necessários, embora outras vezes excessivos.

Como dito, a censura à imprensa pode ocorrer antes ou depois da publicação das notícias. A censura a posteriori se dá através das condenações ao pagamento de indenizações por danos morais eventualmente causados por alguma publicação. Entende-se que tais responsabilizações posteriores são uma forma de censura, pois, muitas vezes, elas levam inclusive ao fechamento de diversos jornais, em especial os de pequeno porte, que não suportam as elevadas indenizações a que são obrigados a pagar e acabam por encerrar as suas atividades, fazendo com que as futuras expressões daquele veículo fiquem impossibilitadas. Ademais, ainda que o fechamento não ocorra, a censura ulterior gera um efeito inibidor semelhante ao da censura prévia, já que tanto o meio de comunicação ou o jornalista censurado quanto os outros veículos acabam por autocensurar-se, na tentativa de evitar condenações semelhantes. Essa "nova" forma de censura é muito mais difícil de controlar e de regular do 
que a censura prévia, já que se trata de uma maneira difusa de controle em que não há como punir os culpados ${ }^{2}$.

Para investigar as limitações impostas pelo Poder Judiciário à imprensa será feita uma análise das decisões através das quais elas se dão, verificando como são ponderados no caso concreto, de um lado, as liberdades de imprensa e a vedação da censura, e, de outro, os direitos da personalidade e a proteção do segredo de justiça e da imparcialidade dos julgadores.

Para tanto, no Capítulo I serão apresentados os conceitos das liberdades de expressão, de imprensa e de comunicação e do direito à informação, suas proteções constitucionais e legais e a importância desses para a democracia e a sociedade pluralista.

Ver-se-á que a Constituição Federal de 1988 concedeu posição de destaque às liberdades de expressão, imprensa, comunicação e ao direito à informação, e que, pela importância que têm para a democracia, para alguns doutrinadores e também a jurisprudência do Supremo Tribunal Federal, a eles deve ser conferida posição de preferência no conflito com outros diretos fundamentais.

Em seguida, no Capítulo II, debruçar-se-á sobre as espécies de restrições às liberdades de expressão, imprensa, comunicação e ao direito à informação para então, no Capítulo III, tratar da relação entre os meios de comunicação e o Poder Judiciário, em especial da influência exercida pelo jornalismo investigativo nas investigações policiais e judiciais e nas decisões dos juízes e jurados.

Por fim, no Capítulo IV, serão analisadas algumas decisões judiciais e os argumentos nelas utilizados, para que assim se possa avaliar de que forma o Poder Judiciário justifica a censura imposta à imprensa.

\footnotetext{
${ }^{2}$ BERTONI, Eduardo Andrés. Liberdad de expresión em el Estado de derecho: doctrina e jurisprudencia nacional, extranjera e internacional. $2^{\mathrm{a}}$ ed. Ciudad Autónoma de Buenos Aires: Del Puerto, 2007. p. 84.
} 
Ao longo de todo este trabalho, além das definições e opiniões doutrinárias, a metodologia utilizada será, prioritariamente, a da análise jurisprudencial. Afinal, o objetivo desta monografia é justamente procurar entender como tem se posicionado o Poder Judiciário na defesa das liberdades democráticas.

O que se propõe, nesta curta jornada, é trazer alguma contribuição por menor que seja - para o debate, indagando e refletindo sobre se, em alguma ou em até que medida, as restrições impostas pelo Poder Judiciário aos meios de comunicação têm razão de ser. 


\section{LIBERDADES DE EXPRESSÃO, IMPRENSA, COMUNICAÇÃO E DIREITO À INFORMAÇÃO}

Neste capítulo serão apresentados os conceitos das liberdades de expressão, imprensa e comunicação e do direito à informação, conceitos esses fundamentais para a análise, que será feita adiante, do confronto dessas liberdades com os direitos da personalidade e a preservação do segredo de justiça e da imparcialidade do juiz, bem como para avaliar a relação entre os meios de comunicação e o Poder Judiciário, no que se refere aos limites impostos por esse àqueles.

A difusão de notícias, de pensamentos e de juízos de valor tem recebido na doutrina diversos nomes, sendo, por vezes, classificada em liberdade de expressão, liberdade de imprensa e direito à informação, outras vezes nomeando-se de "liberdade de expressão e de comunicação" o conjunto dessas liberdades. Tratar-se-á, aqui, de todos esses conceitos.

\section{$1.1 \quad$ Liberdade de Expressão}

A liberdade de expressão - ou direito de opinião, como prefere VIDAL SERRANO ${ }^{3}$ - é a liberdade de pensar e manifestar pensamentos, é o direito de formular ideias, opiniões, convicções e juízos de valor e exteriorizá-los ${ }^{4}$, por qualquer forma ou veículo, sem restrição.

À liberdade de expressão são tradicionalmente atribuídas, pela doutrina, duas concepções. A primeira delas é a concepção libertária ou substantiva, que tem relação com a autorrealização do homem e o desenvolvimento de sua personalidade 5 . A segunda concepção é a democrática ou instrumental, pela qual a liberdade de expressão é vista

\footnotetext{
${ }^{3}$ JÚNIOR, Vidal Serrano Nunes. A Proteção Constitucional da Informação e o Direito à Crítica Jornalística. Coordenação: Hélio Bicudo. São Paulo: FTD, 1997. p. 24.

${ }^{4}$ Ibid. p. 25.

${ }^{5}$ SCHREIBER, Simone. Liberdade de Expressão: Justificativa Teórica e a Doutrina da Posição Preferencial no Ordenamento Jurídico. In: BARROSO, Luis Roberto (Org.). A Reconstrução democrática do direito público no Brasil. São Paulo: Renovar, 2007. p. 229.
} 
como instrumento necessário à constituição e ao funcionamento de uma sociedade plural e, portanto, democrática, uma vez que o pluralismo é fundamento da democracia ${ }^{6}$.

O direito de expressar-se livremente está, assim, em sua concepção democrática, relacionado com a autodeterminação do indivíduo ${ }^{7}$, com o direito de ter ideias diferentes e de discordar de opiniões de qualquer pessoa e até mesmo do Estado, o que possibilita a participação de todos na vida pública.

A Constituição Federal de 1988 concedeu posição de destaque à liberdade de expressão em ambas as concepções. São direitos fundamentais previstos no artigo $5^{\circ}$ da Carta Magna: a livre manifestação do pensamento, nos incisos IV, VI e IX, o direito de resposta, no inciso V, e o direito à informação, presente nos incisos XIV e XXXIII.

Para que a manifestação das ideias, opiniões e pensamentos possa ser de fato livre é necessária, mais do que a não censura, mais do que de uma inação do Estado, uma atitude positiva por parte desse.

Para CELSO RIBEIRO BASTOS, há dois parâmetros para a garantia da liberdade de opinião ou expressão. O primeiro deles é o valor da indiferença, pelo qual o Estado deve manter-se neutro, não levando em consideração o teor das opiniões manifestadas ${ }^{8}$. O segundo é o valor da exigência ${ }^{9}$, que traduz a ideia de que, além de ser ele mesmo neutro, o Estado deve, ainda, exigir o respeito, por parte dos cidadãos, ao pensamento dos outros cidadãos e assegurar o acesso aos meios de expressão. Afinal, de

\footnotetext{
${ }^{6}$ Assim declarou o Ministro Carlos Ayres Britto, no julgamento da ADPF n ${ }^{\circ} 130$ : "O $§ 5^{\circ}$ do art. 220 apresenta-se como norma constitucional de concretização de um pluralismo finalmente compreendido como fundamento das sociedades autenticamente democráticas". STF, ADPF 130, Rel. Ministro Carlos Britto. Brasília, 30 abr. 2009. (grifei)

${ }^{7}$ TAVARES, André Ramos, p. 551 Apud MAYER-PFLUG, Samantha Ribeiro. Liberdade de Expressão e Discurso do Ódio. São Paulo: Editora Revista dos Tribunais, 2010. p. 68.

${ }^{8}$ BASTOS, Celso Ribeiro. Curso de Direito Constitucional. $11^{\mathrm{a}}$ ed. São Paulo: Saraiva, 1989. p. 41.

${ }^{9}$ Ibid. p. 41 .
} 
nada adianta não haver censura se não houver meios para que o pensamento atinja seus emissores.

Nesse sentido, a liberdade de expressão garante que nenhuma ideia seja proclamada como única e verdadeira, mas que, ao contrário, toda e qualquer ideia possa expressar-se ${ }^{10}$.

Da liberdade de expressão aflora todo um sistema de liberdades, dentre as quais se destacam, pela importância que têm para este trabalho, as liberdades de comunicação e imprensa e o direito à informação, que serão analisados abaixo.

Como qualquer direito fundamental, a liberdade de expressão não é absoluta. A expressão de uma opinião ou pensamento não pode prejudicar a expressão de outro pensamento ou opinião, ou, nas palavras de JÜRGEN HABERMAS, na busca por espaços mais democráticos de deliberação, a expressão de um argumento não pode afastar o outro, sob pena de haver impedimentos à participação de todos os interessados ${ }^{11}$.

Apesar de não ser, como nenhum direito o é, absoluto, a liberdade de expressão possui, segundo doutrina desenvolvida nos Estados Unidos ${ }^{12} \mathrm{e}$ hoje já reconhecida pelo Supremo Tribunal Federal, uma posição preferencial - preferred position - em relação a outros direitos, como se extrai do trecho do acórdão a seguir transcrito:

“(...) o direito de crítica em nenhuma circunstância é ilimitável, porém adquire um caráter preferencial, desde que a crítica veiculada se refira a assunto de interesse geral, ou que tenha relevância pública, e guarde pertinência com o objeto da notícia, pois tais aspectos é que fazem a importância da crítica na opinião pública." 13

\footnotetext{
${ }^{10}$ MAYER-PFLUG, Samantha Ribeiro. Op. cit. p. 74.

11 NORONHA, Joanna; SANTANA, Carolina. Jürgen Habermas. Ética Discursiva e Sujeito Deliberativo. p. 05.

${ }^{12}$ FARIAS, Edilsom Pereira de. Colisão de direitos: a honra, a intimidade e a imagem versus a liberdade de expressão e informação. Porto Alegre: Sérgio Antonio de Fabris, 2000. p. 167.

${ }^{13}$ STF, Pet. 3486/DF, Rel. Ministro Celso de Mello. Brasília, 22 ago. 2005. (grifei)
} 
Assim, de acordo com a referida doutrina, quando houver um conflito entre a liberdade de expressão e qualquer outro direito, essa, a princípio, prevalecerá. Isso se deve ao fato de que, pelos motivos já expostos, a liberdade de expressão é fundamental para a democracia e essa, por sua vez, é muito cara a um povo, mais ainda ao povo brasileiro, ainda marcado pela tão recente experiência autoritária, terminada pouco antes do início da vigência da Constituição Federal de 1988.

Da posição de preferência da liberdade de expressão resulta a absoluta excepcionalidade da proibição prévia de expressões, reservando-se essa medida aos raros casos em que não seja possível a composição posterior do dano que eventualmente seja causado a outros direitos fundamentais.

Para garantir o não impedimento prévio do exercício da liberdade de expressão, a Constituição Federal previu, no $\S 2^{\circ}$ do artigo 220 , a proibição de qualquer tipo de censura ${ }^{14}$, ressalvados os casos excepcionais acima citados, assunto que será tratado no Capítulo II deste trabalho.

\subsection{Conceito de imprensa e sua liberdade}

A palavra imprensa, historicamente, está ligada à chamada "prensa", máquina usada, desde o século $\mathrm{XV}$, para imprimir ${ }^{15}$. Com o passar do tempo, passou a definir também qualquer produto impresso, em especial jornais e periódicos, que fossem destinados à divulgação ao público ${ }^{16}$.

A Lei de Imprensa (Lei 5.250 de 1967), revogada integralmente após o julgamento, pelo Supremo Tribunal Federal, da Arguição de

\footnotetext{
${ }^{14}$ No Capítulo II discutir-se-á se a Constituição de fato proíbe qualquer tipo de censura ou se apenas veda a censura administrativa e prévia.

${ }^{15}$ CARVALHO, Luís Gustavo Grandinetti Castanho de. Liberdade de Informação e o Direito difuso à informação verdadeira. Rio de Janeiro: Renovar, 1994. p. 23.

${ }^{16}$ LEYSER, Maria Fátima Vaqueiro Ramalho. Direito à Liberdade de Imprensa. São Paulo: J. de Oliveira, 1999. p. 57.
} 
Descumprimento de Preceito Fundamental $n^{\mathrm{o}} 130^{17}$, incluiu, no conceito de imprensa, os serviços de radiodifusão, leia-se televisão e rádio, e as agências de notícias.

Com isso, alargou-se o conceito de imprensa, que passou a designar "todos os meios de divulgação de informação ao público" 18 ou, ainda, “informação, jornalismo, independentemente do processo que a gerou" 19 .

Mais recentemente, com advento da internet, o termo imprensa passou a designar também as informações divulgadas pela rede mundial de computadores, o que reforça a tese de que o que prepondera é a atividade e não o meio empregado para divulgá-la, seja através da radiodifusão, de meios impressos ou de qualquer outro. Nas palavras de Luís GuSTAVo GRANDINETTI:

\footnotetext{
"Neste conceito podemos incluir como imprensa a atividade jornalística dos jornais, revistas, periódicos, televisão, rádio e a internet. $\mathbf{O}$ que prepondera é a atividade e não o meio empregado para divulgá-la". ${ }^{20}$
}

Tem-se preferido, no entanto, denominar o conjunto dos veículos protegidos pela liberdade acima referida de "meios de comunicação" ou, ainda, simplesmente "mídia", termo que, apesar da conotação pejorativa que adquiriu, deriva da expressão anglo-latina mass media, que designa, por sua vez, meios de comunicação de massa, já que o termo media é, em latim, o plural de medium, ou, simplesmente, "meio" 21.

A liberdade de imprensa, que, como já citado, deriva da liberdade de expressão, indica o direito dos meios de comunicação de divulgarem fatos e opiniões. Difere da liberdade de informação na medida em que se refere ao interesse público na livre circulação de ideias e, portanto, pertence aos

\footnotetext{
${ }^{17}$ STF, ADPF 130, Rel. Ministro Carlos Britto. Brasília, 30 abr. 2009.

${ }^{18}$ CALDAS, Pedro Frederico. Vida privada, liberdade de imprensa e dano moral. $2^{\mathrm{a}}$ ed. São Paulo: Saraiva, 1997. p. 64.

${ }^{19}$ CARVALHO, Luís Gustavo Grandinetti Castanho de. Liberdade de Informação e o Direito difuso à informação verdadeira. Op. cit. p. 23.

${ }^{20}$ Ibid. p. 24.

${ }^{21}$ FARIAS, Edilsom Pereira de. Liberdade de Expressão e Comunicação, teoria e proteção constitucional. São Paulo: Editora Revista dos Tribunais, 2004. p. 100.
} 
meios de comunicação, enquanto que o direito à informação, como se verá abaixo, é um direito individual, cuja titularidade é concedida a todos os cidadãos.

\subsection{Liberdade de Comunicação versus Liberdade de Expressão}

EDILSOM FARIAS sugere que seja adotado, de forma genérica, o nome "liberdade de expressão e comunicação" para designar o conjunto das liberdades de manifestação do pensamento, ideias, crenças e juízos de valor, como forma de reduzir a imprecisão gerada pela profusão de nomes existentes na doutrina para designá-las ${ }^{22}$.

Entende o autor que a palavra "comunicação" expressa melhor o atual complexo de fatos e notícias existente na vida social, e a palavra "expressão" abrange as liberdades de pensamento, opinião, de consciência, de ideia, de crença e de juízo de valor ${ }^{23}$.

Dessa forma, o termo "comunicação" define a difusão de fatos ou notícias e a palavra "expressão" resume a manifestação de pensamento, ideias, opiniões, crenças e juízos de valor.

A importância da distinção entre as duas liberdades, de acordo com o citado autor, está no fato de que, como a liberdade de expressão tem conteúdo subjetivo e abstrato, ela não está submetida ao exame da verdade, enquanto que o conteúdo da liberdade de comunicação é objetivo e, portanto, suscetível de comprovação da verdade ${ }^{24}$.

Assim, a informação ou a notícia veiculada por qualquer meio de comunicação não pode prescindir da verdade, pelo fato de que é isso que as pessoas legitimamente supõem estar conhecendo ao buscá-la. Já quando se

\footnotetext{
${ }^{22}$ Ibid. p. 52.

${ }^{23}$ Ibid. p. 53

${ }^{24}$ Ibid. p. 55.
} 
cuida de manifestações da liberdade de expressão não se cogita o requisito da verdade. Nas palavras de GRANDINETTI:

\footnotetext{
"Todos os doutrinadores citados, mesmo os que, em maioria, adotam uma disciplina comum entre expressão e informação, deparam-se com, pelo menos, uma distinção importante entre os dois institutos: a veracidade e a imparcialidade da informação. E é justamente em razão dessa distinção fundamental que se deve pensar em um direito de informação que seja distinto em sua natureza da liberdade de expressão". ${ }^{25}$
}

Para JosÉ AFONSO DA SILVA, a liberdade de comunicação compreende as várias formas de criação, expressão e manifestação do pensamento e de informação, bem como a organização dos meios de comunicação $^{26}$, que hoje, como dito acima, vão muito além do jornal impresso.

Além da liberdade de publicar qualquer notícia ou opinião, para JOSÉ AFONSO, a liberdade de comunicação depende ainda da liberdade de criação e funcionamento dos meios de comunicação. Também para VIDAL SERRANO, além da preservação da expressão da opinião quando exteriorizada em algum meio de comunicação, o que está previsto nos artigos $220, \S \S 1^{\circ}$ a $4^{\circ}$ e 221 da Constituição Federal, o direito ou liberdade de comunicação envolve ainda a preservação da existência e do funcionamento dos meios de comunicação, que devem ser disciplinados, por exemplo, pelas normas de concessão de rádio e televisão, nos termos dos artigos $220, \S \S 5^{\circ}$ e $6^{\circ}, 222,223$ e 224 da Carta Magna ${ }^{27}$.

No Brasil, os meios de publicação de livros e periódicos, bem como de escritos pela internet, não dependem de nenhuma licença para serem criados ou funcionar. Já os serviços de radiodifusão são explorados diretamente pela União ou mediante concessão, permissão ou autorização,

\footnotetext{
${ }^{25}$ CARVALHO, Luís Gustavo Grandinetti Castanho de. Direito de informação e liberdade de expressão. Rio de Janeiro: Renovar, 1999. p. 24.

${ }^{26}$ SILVA, José Afonso da. Curso de Direito Constitucional Positivo. $28^{\mathrm{a}}$ ed. São Paulo: Malheiros, 2007. p. 243.

${ }^{27}$ JÚNIOR, Vidal Serrano Nunes. Op. Cit. p. 30.
} 
nos termos dos artigos, 21, inciso XII, alínea $a$ e artigo 223 da Constituição Federal, não sendo, portanto, de livre criação ${ }^{28}$.

\subsection{Direito à informação}

\subsubsection{As facetas do Direito à informação}

A liberdade de informação inclui o direito individual de informar, ou de comunicar fatos objetivamente considerados, e o direito, do cidadão, de ser informado, ou melhor, o direito de receber informações.

VIDAL SERRANO vai além ao dizer que o direito à informação contempla o direito de informar, de veicular informações em qualquer meio, o direito de ser informado, integral e corretamente, e o direito de se informar, que está presente no inciso XIV do artigo $5^{\circ}$ e é garantido pelo remédio constitucional previsto no inciso LXXII do mesmo artigo, no que se refere ao direito de obter informações sobre si em bancos de dados públicos. Esses três direitos, segundo o autor, seriam interdependentes, já que só é possível ser informado se alguém informar e só é possível informar se houver público receptor das informações ${ }^{29}$.

Ressalte-se, ainda, que o direito de acesso de todos à informação engloba também o direito ao sigilo da fonte, previsto no inciso XIV do artigo $5^{\circ}$, quando esse é necessário ao exercício da profissão de jornalista ou comunicador social. Os jornalistas e os meios de comunicação sempre responderão, no entanto, pelos abusos e prejuízos causados pelas informações que trouxerem ${ }^{30}$.

O direito à informação tem suas raízes na liberdade de imprensa, que, por sua vez, como já dito, deriva da liberdade de expressão. Quando a

\footnotetext{
${ }^{28}$ SILVA, José Afonso da. Op. Cit. p. 244 e 248.

${ }^{29}$ JÚNIOR, Vidal Serrano Nunes. Op. Cit. p. 31.

${ }^{30}$ SILVA, José Afonso da. Op. Cit. p. 246.
} 
liberdade de imprensa surgiu, na França revolucionária, em 1789, e nos Estados Unidos, em 1791, estava ligada exclusivamente aos jornais e periódicos impressos. Hoje, com a proliferação de meios de comunicação, a liberdade de imprensa assumiu, de acordo com o já citado autor VIDAL SERRANO, a forma moderna de liberdade de informação jornalística. Até mesmo na Declaração de Direitos do Homem e do Cidadão, de 1948, a expressão "liberdade de imprensa" foi substituída pela liberdade de transmitir informações e ideias por quaisquer meios e independentemente de fronteiras. Apesar da mudança de nome, o direito protegido, o livre fluxo de informações e opiniões, continua a ser o mesmo ${ }^{31}$.

\subsubsection{As acepções positiva e negativa do direito à informação}

Os direitos de primeira geração, típicos do Estado liberal, são as chamadas liberdades negativas, ou seja, direitos dos cidadãos contra o Estado. Ao Estado, nesse caso, não cabe nenhuma atitude, nenhuma concessão de direitos, mas apenas um não-fazer. Exemplo desses direitos são os direitos individuais. Com a criação do Estado social, surgem os direitos de segunda geração, de que são exemplo os direitos sociais, aqueles em que há uma atitude positiva do Estado, uma ação e não apenas um nãofazer.

A concepção liberal clássica da liberdade de expressão está justamente relacionada com a ideia de liberdade negativa. No Estado liberal, a liberdade de expressão estava associada simplesmente à ausência de censura ${ }^{32}$. Hoje, no entanto, o Estado age na busca de garantias desse direito e a liberdade de expressão é muito mais do que o simples nãoimpedimento à livre expressão.

\footnotetext{
${ }^{31}$ JÚNIOR, Vidal Serrano Nunes. Op. Cit. p. 37.

${ }^{32}$ FARIAS, Edilsom Pereira de. Liberdade de Expressão e Comunicação, teoria e proteção constitucional. Op. Cit. p. 77.
} 
De acordo com Luís GUSTAVo GRANDINETTI, a transformação do Estado liberal em Estado Social dependeu também, dentre outros fatores, da adição à liberdade de imprensa do dever de informar dos meios de comunicação e do direito de ser informado da população ${ }^{33}$. Isso porque, com a criação de um direito contraposto a um dever de informação, o Estado deixou de apenas conceder uma liberdade negativa e passou a promover um direito.

Apesar da atual concepção acima descrita, a Constituição Federal não prevê o dever de informar, mas apenas a liberdade de veicular informações. Assim, o direito previsto na Constituição brasileira é ainda uma liberdade negativa por parte do Estado, um direito de primeira geração de não ter a intromissão estatal na atividade jornalística privada.

Nesse sentido, o direito de ser informado não é absoluto, já que depende do exercício do direito de informar e a Constituição não atribui a nenhum órgão o dever de informar, salvo no que se refere às atividades públicas, como prescrevem os artigos $5^{\circ}$, inciso XXXIII e 37, caput e $\S 1^{\circ}$.

A única exceção, na Constituição, a essa liberdade negativa é o direito de resposta, previsto no artigo $5^{\circ}$, inciso $\mathrm{V}$, em que o direito de informar assume feição positiva. Nesse caso, passa-se a ter direito a ter meios para veicular informações, e não apenas a liberdade de fazê-lo, sempre que, ao sentir-se ofendido por uma informação ou opinião já veiculada, se conquistar esse direito no Judiciário. ${ }^{34}$

\subsubsection{Direito à difusão de notícias e direito à crítica}

$\mathrm{O}$ direito de informar, em sua acepção negativa, se subdivide em direito de transmitir notícias e em direito de emitir ideias, conceitos, opiniões, críticas e comentários a essas notícias, ou seja, em direito de

\footnotetext{
${ }^{33}$ CARVAlHO, Luís Gustavo Grandinetti Castanho de. Liberdade de Informação e o Direito difuso à informação verdadeira. Op. Cit. p. 50.

${ }^{34}$ JÚNIOR, Vidal Serrano Nunes. Op. Cit. p. 32.
} 
transmitir notícias publicamente e direito à expressão pública de ideias e opiniões $^{35}$.

A despeito do atual conceito alargado de notícia, em que qualquer informação sobre a vida alheia é considerada noticiável, para este trabalho, considerar-se-á notícia toda nota ou anotação sobre fatos ou pessoas cujo conhecimento seja necessário para possibilitar a concreta participação na vida coletiva da sociedade ${ }^{36}$, podendo ou não vir agregada de uma crítica.

$\mathrm{O}$ direito à crítica, ou seja, o direito de emitir opiniões pessoais, favoráveis ou não, sobre um fato, parte do direito à informação, e deve estar sempre relacionado à notícia ${ }^{37}$. Assim, se a crítica for dirigida a outros fatos ou pessoas não retratados na notícia, tratar-se-á de direito de opinião, ou liberdade de expressão, e não direito à crítica. Dessa forma, o direito à crítica nada mais é que o direito de opinião sobre uma determinada notícia.

A necessária ligação entre a crítica e a notícia a que se refere é evidenciada pelo fato de que o direito à crítica nunca teve, no Brasil, tratamento constitucional específico, sendo sempre derivado do direito de informação.

\subsubsection{A função social do direito à informação}

Para JOSÉ AFONSO DA SILVA, a liberdade de informação não pertence simplesmente à empresa jornalística ou ao jornalista, mas, ao contrário, a liberdade a eles conferida apenas se justifica na medida em que os indivíduos têm o direito a ter informações corretas e imparciais ${ }^{38}$. Assim, os meios de comunicação e os jornalistas têm, em verdade, um dever, mais do que um direito, de informar, de forma objetiva e verdadeira, à coletividade, os acontecimentos e suas ideias.

\footnotetext{
${ }^{35}$ Ibid. p. 34.

${ }^{36}$ Ibid. p. 35.

${ }^{37}$ Ibid. p. 39

${ }^{38}$ SILVA, José Afonso da. Op. Cit. p. 247.
} 
O titular da liberdade de informação é, na lição de RAMON SORIANO, a pessoa enquanto tal e não o profissional da comunicação ${ }^{39}$. Assim, apesar de a liberdade de informação encontrar seus limites na própria Constituição Federal, nenhuma lei, nem mesmo a Constituição, pode reduzi-la a uma determinada categoria de pessoas, vez que a titularidade da liberdade de informação, como dito, é genérica.

A concepção democrática da liberdade de expressão, tratada linhas acima, também conhecida como concepção objetiva, foi defendida por JAMES MADISON, mentor da Primeira Emenda dos EUA, e por ALEXANDER MAIKLEJOHN, que vislumbrava uma dupla função na liberdade de expressão. A primeira delas era a função informativa, que permitiria aos cidadãos uma melhor avaliação dos assuntos de relevância pública. A segunda é a função crítica, pela qual seria possível questionar os poderes políticos e os agentes públicos ${ }^{40}$.

ALEXIS DE TOCQUEVILLE, referindo-se ao papel do jornal em uma sociedade democrática, resume a função fundamental dos meios de comunicação - função essa que assumiu, hoje, ainda maior relevância com o alargamento do alcance que lhes foi proporcionado pelo avanço tecnológico - da seguinte forma:

"Não negarei que, nos povos democráticos, os jornais muitas vezes levam os cidadãos a tomar em comum iniciativas insensatas; mas, se não houvesse jornais, quase não haveria ação comum. O mal que eles produzem é, portanto, bem menor do que o mal que curam.",11

Diz José Afonso, ainda, que os meios de comunicação são, hoje, um quarto poder, na medida em que funcionam como instrumento de formação da opinião pública e de controle sobre a atividade políticofinanceira. Os meios de comunicação têm, como se vê, uma função social a

\footnotetext{
${ }^{39}$ SORIANO, Ramon. Las Libertades Públicas. Madri: Techonos, 1999. p. 144.

${ }^{40}$ FARIAS, Edilsom Pereira de. Liberdade de Expressão e Comunicação, teoria e proteção constitucional. Op. Cit. p. 71.

${ }^{41}$ TOCQUEVILLE, Alexis de. A Democracia na América: Livro II, Sentimentos e Opiniões. Tradução: Eduardo Brandão. São Paulo: Martins Fontes, 2004. p. 137. (grifei)
} 
cumprir e essa função social justifica, de acordo com o referido autor, o condicionamento e a limitação da sua liberdade de informar, seja pela vedação do anonimato, pelo direito de resposta proporcional ao agravo ou, ainda, pela indenização por danos morais e materiais dos ofendidos em sua imagem ou moral ${ }^{42}$.

Dessa forma, a imprensa, na sua acepção mais alargada expressa linhas acima, se apresenta como órgão responsável pela exteriorização e a atualização da vontade popular e da opinião pública, contribuindo para a preservação da democracia, na medida em que fomenta o debate público e a livre discussão de ideias ${ }^{43}$.

Por esse motivo, exige a Constituição, no artigo 222, que a propriedade de empresas jornalísticas seja privativa de brasileiros natos ou naturalizados há mais de dez anos, evitando-se, assim, que um estrangeiro possa controlar a opinião pública brasileira.

Para José Gomes CANOTILHO, mais do que assegurar a liberdade de informar dos meios de comunicação, devem os governos garantir a independência deles, já que a ingerência, em especial, do poder econômico nesses meios pode gerar a manipulação da informação, prejudicando a formação da opinião pública ${ }^{44}$. Pelo mesmo motivo, veda a Constituição, no $\S 5^{\circ}$ do artigo 220 , que os meios de comunicação sejam objeto de monopólio ou oligopólio, de forma a permitir o acesso aos meios de comunicação de diferentes correntes ideológicas e favorecer o pluralismo político ${ }^{45}$.

Para EDILSOM FARIAS, a expressão que melhor representa o neste item exposto não é a "liberdade de informação", mas sim "liberdade de expressão e comunicação", já que, etimologicamente, o termo comunicação

\footnotetext{
${ }^{42}$ SILVA, José Afonso da. Op. Cit. p. 247.

${ }^{43}$ MAYER-PFLUG, Samantha Ribeiro. Op. cit. p. 49.

${ }^{44}$ CANOTILHO, José Joaquim Gomes; MOREIRA, Vital. Constituição da República Portuguesa. São Paulo: Revista dos Tribunais, 2007. p. 241.

${ }^{45}$ MAYER-PFLUG, Samantha Ribeiro. Op. cit. p. 51.
} 
significa transmissão ou compartilhamento de algo de que se dispõe, enquanto a informação é apenas o objeto da comunicação ${ }^{46}$.

\subsection{Breve histórico das liberdades de comunicação e expressão}

A afirmação da liberdade de expressão e de comunicação como direito fundamental remonta aos Estados surgidos das revoluções americana e francesa, respectivamente em 1776 e $1789^{47}$.

A tão conhecida Primeira Emenda, de 1791, à Constituição dos Estados Unidos, consagra a célebre, e até hoje vigente, vedação pela qual o Congresso não legislará para cercear a liberdade de imprensa ${ }^{48}$.

Também na França, tanto na Declaração de Direitos do Homem e do Cidadão, de 1789, quanto na Constituição de 1793, foram proclamadas as liberdades de imprensa e de manifestação do pensamento. ${ }^{49}$

A Assembléia Geral das Organizações das Nações Unidas, já em 1946, declarou a liberdade de informação - foi assim denominada, como dito acima - a mais importante de todas as liberdades, e a Declaração Universal de Direitos Humanos, de 1948, foi moderna ao estabelecer que a difusão de ideias poderia se dar por quaisquer meios e independentemente de fronteiras. ${ }^{50}$

No Brasil, a liberdade de expressão esteve garantida desde a primeira Constituição, de 1824. As exceções a essa liberdade é que aumentavam ou diminuíam nas Constituições, de acordo com o grau de democracia do período.

\footnotetext{
${ }^{46}$ FARIAS, Edilsom Pereira de. Liberdade de Expressão e Comunicação, teoria e proteção constitucional. Op. Cit. p. 54.

${ }^{47}$ Ibid. p. 58.

${ }^{48}$ FISS, M. Owen. A Ironia da Liberdade de Expressão: Estado, Regulação e Diversidade na Esfera Pública. Tradução e Prefácio de Gustavo Binenbojm e Caio Mário da Silva Pereira Neto. Rio de Janeiro: Renovar, 2005. p. 33.

${ }^{49}$ FARIAS, Edilsom Pereira de. Liberdade de Expressão e Comunicação, teoria e proteção constitucional. Op. Cit. p. 60.

${ }^{50}$ Ibid. p. 61.
} 
A Carta de 1824, outorgada por D. Pedro I, já previa a liberdade de comunicação e de pensamento, independentemente de censura, ressalvada a responsabilidade pelos abusos que fossem cometidos no seu exercício ${ }^{51}$.

A Primeira Constituição Republicana, de 1891, trouxe texto semelhante ao da Carta anterior, tendo sido apenas acrescentada a vedação do anonimato ${ }^{52}$.

A Constituição de 1934, por sua vez, manteve o texto da Constituição de 1891, mas acrescentou, além do direito de resposta e da não exigência de licença do poder público para a publicação de livros e periódicos, pela primeira vez, apesar de seu caráter democrático, que não seria tolerada a propaganda de guerra ou de processos de subversão da ordem política ou social. ${ }^{53}$

Na Carta autoritária de 1937, as restrições à liberdade de expressão se acentuaram, o que refletia o momento político de concentração de poder nas mãos do chefe do Poder Executivo. Para o autor da Carta outorgada de 37, FRANCISCO CAMPOS, apesar de o texto prever a liberdade de expressão e opinião, em seguida estabelecia a censura prévia, o que negava a liberdade e, ao mesmo tempo, deixava clara a opção pelo regime antidemocrático $^{54}$. A ingerência, então, do Governo nos meios de comunicação era tal que a Constituição determinava a impossibilidade de recusa a veicular comunicados do governo. Estabelecia, ainda, a Carta de 1937, à semelhança da Constituição de 1988, que a direção das empresas jornalísticas era cargo exclusivo de brasileiro nato, no que é mais rigorosa do que a Constituição atual, pela pretensão nacionalista do período ${ }^{55}$.

\footnotetext{
${ }^{51}$ NOGUEIRA, Octaciano. Constituições Brasileiras: 1824. $2^{\mathrm{a}}$ ed. Brasília: Senado Federal; Ministério da Ciência e Tecnologia, Centro de Estudos Estratégicos, 2001. p. 103.

52 BALEEIRO, Aliomar. Constituições Brasileiras: 1891. $2^{\mathrm{a}}$ ed. Brasília: Senado Federal; Ministério da Ciência e Tecnologia, Centro de Estudos Estratégicos, 2001. p. 98.

${ }^{53}$ POLETTI, Ronaldo. Constituições Brasileiras: 1934. $2^{\mathrm{a}}$ ed. Brasília: Senado Federal; Ministério da Ciência e Tecnologia, Centro de Estudos Estratégicos, 2001. p. 158.

${ }^{54}$ PORTO, Walter Costa. Constituições Brasileiras: 1937. $2^{\mathrm{a}}$ ed. Brasília: Senado Federal; Ministério da Ciência e Tecnologia, Centro de Estudos Estratégicos, 2001. p. 44.

${ }^{55}$ Ibid. p. 101.
} 
Destaque-se, ainda, que foi sob a égide da Carta de 1937 que foi criado, em 1939, o Departamento de Imprensa e Propaganda, que, além de realizar a censura à imprensa, com base no Decreto 1.949, de 1939, era responsável por difundir a ideologia do Estado Novo, sobre o que será tratará no Capítulo II desta obra.

A Constituição liberal de 1946, no que se refere à liberdade de pensamento e expressão, caminhou no mesmo sentido da Constituição de 1934, retomando a tradição democrática, também estabelecendo a intolerância à propaganda de guerra ou de processos de subversão da ordem política ou social, acrescentando, ainda, a rejeição ao preconceito de raça ou de classe ${ }^{56}$.

Em 1965, ainda durante a vigência da Constituição de 1946, foi publicado o Ato Institucional $\mathrm{n}^{\circ} 02$, que, dentre outras determinações antidemocráticas, estabeleceu que ficava proibida a manifestação ou a atividade sobre assuntos de natureza política, assunto que será retomado no Capítulo II a seguir, quando se abordará a censura prévia no período da Ditadura Militar.

Após curto período de retorno às tradições liberais e democráticas, a Carta de 1967 voltou a constitucionalizar um regime autoritário, estabelecendo, no que se refere às liberdades de expressão, manifestação do pensamento e opinião, fortes restrições. Apesar de prever a vedação da censura, a Constituição de 1967 trazia, mais uma vez, como o fez a Constituição de 1946, a intolerância à propaganda de guerra ou de processos de subversão da ordem política ou social e rejeição ao preconceito de raça ou de classe, passando a repudiar, ainda, as publicações

\footnotetext{
56 BALEEIRO, Aliomar. Constituições Brasileiras: 1946. $2^{\mathrm{a}}$ ed. Brasília: Senado Federal; Ministério da Ciência e Tecnologia, Centro de Estudos Estratégicos, 2001. p. 99.
} 
e exteriorizações contrárias à moral e os bons costumes ${ }^{57}$, através expressões vagas e, por isso, abrangentes.

Foi durante a vigência da Carta de 1967 que foi editada a já citada Lei 5.250, do mesmo ano, que institucionalizou a censura prévia no Brasil, na forma que será vista no próximo capítulo.

Com a Constituição de 1988, tem-se a volta dos valores democráticos, privilegiando-se todos os tipos de liberdade, bem como a vedação de qualquer espécie de censura. As liberdades de expressão e pensamento são, hoje, além de direitos fundamentais com a importância que resta clara da leitura das páginas supra, cláusulas pétreas ou limitações materiais expressas ao Poder constituinte derivado reformador, nos termos do inciso IV do $\$ 4^{\circ}$ do artigo 60 da Constituição Federal, o que significa que, em nenhuma circunstância, uma reforma constitucional poderá abolilos.

No âmbito internacional, o Brasil é signatário do chamado Pacto de São José da Costa Rica, ratificado em 1992, que estabelece no seu artigo 13, as liberdades de pensamento e de informação, tanto no sentido de recebê-las quanto de fornecê-las, na forma já explicitada acima. Como se verá no capítulo destinado a tratar da censura, o Pacto prevê também a vedação da censura prévia, salvo aos espetáculos, para a proteção moral da infância e da adolescência, e a possibilidade de responsabilização ulterior daqueles que desrespeitarem direitos alheios ou colocarem em risco, no exercício da liberdade de informação, a segurança nacional, a ordem pública, a saúde ou a moral pública, conceitos vagos e, por isso, perigosos. Estabelece, ainda, que a lei deve proibir toda manifestação que incite a guerra ou faça apologia do preconceito ou da discriminação de qualquer tipo. Por fim, determina o Pacto, no artigo 14, que deva a lei conceder

\footnotetext{
${ }^{57}$ BALEEIRO, Aliomar; BRITO, Luiz Navarro de. Constituições Brasileiras: 1967. $2^{\mathrm{a}}$ ed. Brasília: Senado Federal; Ministério da Ciência e Tecnologia, Centro de Estudos Estratégicos, 2001. p. 162.
} 
direito de resposta a todos aqueles que forem atingidos por informações inexatas ou ofensivas.

Cumpre registrar, ainda, que o Brasil é signatário também da Declaração de Chapultepec, uma carta de princípios ratificada em 1996 e reafirmada recentemente no governo Lula, na qual se estabelece que a liberdade de expressão e de imprensa é condição fundamental para a existência de uma sociedade livre. $\mathrm{O}$ documento veda, ainda, o estabelecimento de sanções aos jornalistas que fizerem denúncias ou criticarem o poder público, o que reforça a ideia já aqui expressa de que a função da imprensa é, também, funcionar como órgão fiscalizador dos Poderes Públicos. 


\section{RESTRIÇÕES ÀS LIBERDADES DE EXPRESSÃO, IMPRENSA E COMUNICAÇÃO E DIREITO DE INFORMAR}

Neste capítulo tratar-se-á da evolução, no Brasil, das restrições impostas às liberdades vistas no capítulo anterior. Para tanto, será necessário conceituar censura e ver as formas pelas quais tais restrições podem se dar.

Com isso, será possível avaliar, nos capítulos que se seguem, se as limitações hoje impostas à imprensa pelo Poder Judiciário podem ser consideradas censura e se tais restrições são efetivamente necessárias para a manutenção da autoridade das decisões judiciais e para a preservação da imparcialidade dos julgadores.

\subsection{Conceito de Censura}

Curiosamente, o termo censura é, de modo geral, definido como o exame crítico de obras literárias ou artísticas e de matérias jornalísticas feito, por agentes do poder público, antes da publicação dessas ${ }^{58}$. Isso se deve ao fato de que a censura sempre esteve associada à proibição da divulgação ou da execução de uma obra, ou melhor, às restrições impostas, pelos órgãos estatais, a qualquer escrito previamente à sua publicação. Assim, tradicionalmente, a existência das liberdades de expressão e imprensa esteve relacionada pura e simplesmente com a ausência da censura prévia.

Contudo, também a responsabilização ulterior pelos excessos cometidos por aquele que se expressa deve ser, e é, como será visto neste

\footnotetext{
${ }^{58}$ É assim que a cesura é definida pela maior parte dos dicionários, dentre os quais se destaca o Aurélio. FERREIRA, Aurélio Buarque de Holanda. Coordenado por Margarida dos Anjos e Marina Baird Ferreira. Míni Aurélio: O dicionário da língua portuguesa. $6^{a}$ ed. Curitiba: Positivo, 2005. p. 244.
} 
capítulo, considerada censura, em razão do seu efeito inibidor da expressão, semelhante ao efeito da repressão anterior à publicação.

Nesse sentido, José CRETELLA JÚNIOR, em definição mais ampla, entende por censura:

“(...) o exame a que determinadas autoridades governamentais, moralistas ou eclesiásticas, submetem os meios de comunicação humana (livros, jornais, discursos, sermões, filmes, teatro, televisão, rádio), conforme padrões discricionários fixados pelo centro ou poder dominante dentro de determinados limites estabelecidos em lei, podendo ser prévia ou a priori e posterior" ${ }^{59}$.

A Constituição Federal do Brasil coíbe, no $\S 2^{\circ}$ do artigo 220, qualquer tipo de censura, seja de natureza política, ideológica ou artística. Apesar do disposto no caput do referido artigo, segundo o qual a manifestação do pensamento, a criação, a expressão e a informação não sofrerão qualquer restrição, seu $\S 1^{\circ}$ ressalva o previsto no inciso $X$ do artigo $5^{\circ}$ da Constituição, pelo qual se prevê a possibilidade de responsabilização pelos abusos cometidos no exercício da liberdade de expressão, quando nesse se atingir outros direitos fundamentais.

Dessa forma, apesar de a censura estar expressamente proibida na Constituição, não há nada que impeça a responsabilização ulterior e, portanto, conclui-se que também a Constituição Federal conceituou censura como sendo apenas as restrições prévias impostas às publicações.

\subsection{Tipos de censura}

A censura pode, como visto em definição mais ampla, ser prévia ou posterior, de acordo com o momento em que se dá. E pode ainda, relativamente ao órgão de poder que a aplica, ser administrativa ou judicial, seja ela prévia ou posterior.

\footnotetext{
${ }^{59}$ JÚNIOR, José Cretella. Comentários à Constituição de 1988. v.1. Rio de Janeiro: Forense, 1992. p. 256.
} 


\subsubsection{Quanto ao momento}

\subsubsection{A censura prévia}

A censura prévia, como dito, é a censura tradicional, aquela que o senso comum define como tal. Trata-se do exame crítico de obras, artísticas ou literárias, e de matérias jornalísticas feito por autoridades, governamentais ou não, que pode levar ou não à proibição de sua divulgação.

A vedação da censura prévia é bem antiga e remonta ao século XVIII, quando WILLIAN BLACKSTONE conceituou, pela primeira vez, as liberdades de imprensa e expressão e a proibição da censura prévia, em seus "Commentaries on the Laws of England", conhecida como prior restraint doctrine $^{60}$. Entendia-se então que a liberdade de imprensa estava intimamente relacionada a não imposição de restrições prévias às publicações, já que, com isso, todo homem teria o direito de levar a público opiniões e fatos de seu conhecimento. O objetivo era, assim, que toda ideia pudesse ser expressa ao menos uma vez ${ }^{61}$.

A censura no Brasil foi, historicamente, de modo geral, realizada previamente às publicações. Mais recentemente, como se verá, com a proibição constitucional da censura prévia, passou-se a realizar outra forma de limitação da expressão.

\subsection{Breves notas sobre a censura até o governo Getúlio Vargas}

A censura no Brasil foi, até 1768, realizada de acordo com parâmetros católicos, por três órgãos ligados à Igreja: a Inquisição, o Ordinário e o Desembargo do Paço. Foi nesse ano que Marquês de Pombal,

\footnotetext{
${ }^{60}$ TOLLER, Fernando M. O Formalismo da Liberdade de Expressão. São Paulo: Saraiva, 2010. p. 25.

${ }^{61}$ Ibid. p. 27.
} 
então secretário de Estado do Reino português, com intenção de secularizar a censura, criou a Real Mesa Censória ${ }^{62}$, cujos funcionários eram leigos e indicados pelo rei ${ }^{63}$. Em 1787, no entanto, a então rainha D. Maria I criou a Real Comissão para Exame e Censura dos Livros, fazendo com que a censura voltasse ao jugo católico ${ }^{64}$.

Em 1808, D. João VI criou a censura brasileira, cujos temas rechaçados eram religião, política e bons costumes. Com a Revolução do Porto, em 1820, baixou-se a lei especial da Imprensa, que extinguia de fato e de direito a censura em Portugal ${ }^{65}$, acabando com a Inquisição, órgão censório que funcionou durante três séculos naquele país. Apesar do apoio de D. João ao movimento revolucionário, em 1821, o Príncipe Regente de Portugal editou uma lei prevendo a passagem de qualquer impresso pelo Diretor de Estudos, que avaliaria se havia ou não algo a ser censurado. Com a volta de D. João para Portugal, D. Pedro I, Príncipe Regente do Brasil, oficializou a liberdade de imprensa nesse país, que durou pouco, vez que, em 1822, o Príncipe puniu o jornalista João Soares Lisboa, do jornal "Correio do Rio de Janeiro", que lhe fazia oposição ${ }^{66}$.

Em 1823, D. Pedro fechou a Assembléia Constituinte, prometendo, no entanto, uma Constituição liberal e a edição da lei de imprensa. A lei saiu no mesmo ano e a Constituição no ano seguinte. A lei de imprensa, recém editada, durou pouco, sendo trocada por uma mais liberal, editada em 1830, durando essa última menos ainda que a primeira, já que fora substituída, no mesmo ano, pelo Código Criminal, que continha disposições sobre a imprensa que contrariavam a lei anterior ${ }^{67}$. O Código Criminal e o

\footnotetext{
${ }^{62}$ FAGUNDES, Coriolano de Loyola Cabral. Censura \& liberdade de expressão. São Paulo: Editora Edital e Distribuidora Record, 1974. p. 292.

${ }^{63}$ MARTINO, Aguinaldo; SAPATERRA, Ana Paula. A Censura no Brasil do Século XVI ao Século XIX. In: Estudos Lingüísticos XXXV, 2006, Disponível em http://www.usp.br/proin/download/artigo/artigos_censura_brasil.pdf. Acesso em 05 set. 2010. p. 234-243.

${ }^{64}$ FAGUNDES, Coriolano de Loyola Cabral. Op. Cit. p. 293.

${ }^{65}$ Ibid. p. 293.

${ }^{66}$ Ibid. p. 294.

${ }^{67}$ Ibid. p. 295
} 
Código de Processo Penal prevaleceram até 1889, com a Proclamação da República. Até essa data, muitas foram as controvérsias sobre a revogação ou não da lei de imprensa, uma vez que essa não fora revogada expressamente. Em meio à polêmica, aproveitaram os jornalistas, que puderam expressar-se livremente e mantiveram-se impunes.

A Constituição de 1891 disciplinava, no artigo 72, que era livre a manifestação do pensamento, independentemente de censura, sendo vedado o anonimato. Os delitos de imprensa eram, no entanto, até 1923, disciplinados pelo Código Penal de 1890. Em 1923, no governo de Artur Bernardes, surge a lei especial de imprensa (Lei 4.743), conhecida como "Lei Adolfo Gordo", seu relator no Senado, e apelidada pelos opositores do governo de "lei infame" ${ }^{68}$, por regular a liberdade de imprensa e instituir a censura prévia.

\subsection{Departamento de Imprensa e propaganda: a censura na Era Vargas}

Exemplo clássico de censura prévia e administrativa era a realizada, durante o Estado Novo, pelo Departamento de Imprensa e Propaganda, que teve papel relevante no aumento do poder pessoal de Getúlio Vargas e na quase eliminação de tensões sociais no período. ${ }^{69}$

O chamado governo provisório de Getúlio Vargas, entre 1930 e 1934, foi marcado pela perseguição aos jornais e periódicos. Foi nesse período que aconteceram os empastelamentos dos jornais "Diário Carioca" e "O País", que faziam oposição à Vargas. Com a Revolução Constitucionalista de 1932, foi atenuada a ação contra os meios de

\footnotetext{
${ }^{68}$ Ibid. p. 297.

69 SKIDMORE, Thomas E. Brasil: de Getúlio Vargas a Castelo Branco, 1930-1964. Tradução coordenada por Ismênia Tunes Dantas. $7^{\mathrm{a}}$ ed. Rio de Janeiro: Paz e Terra, 1982. p. 58.
} 
comunicação e, mantendo a linha mais liberal, a Constituição de 1934 previu a vedação da censura, salvo aos espetáculos e diversões públicas ${ }^{70}$.

Em 1935, no entanto, a Lei de Segurança Nacional (Lei $n^{\mathbf{o}} 38$ ) passou a prever, em seu artigo 25 , que se os crimes contra a segurança nacional fossem praticados por meio da imprensa, as respectivas edições poderiam ser apreendidas ${ }^{71}$.

O DIP, de inspiração fascista, que como tal buscava difundir a ideologia do Estado Novo e obter apoio das camadas populares, foi criado em 1939, através do Decreto-lei $\mathrm{n}^{\circ} 1.915$, apesar de ter origem em período anterior $^{72}$.

Dentre outras funções, competia ao DIP patrocinar a Agência Nacional, que garantia a uniformização da informação, distribuindo gratuitamente as matérias e monopolizando o noticiário ${ }^{73}$.

Cabia ao DIP ainda realizar todo tipo de censura. Desta maneira, além de uniformizar a informação, o DIP podia também evitar que informações não fornecidas pela Agência Nacional chegassem ao conhecimento do público.

Em 1945, o governo Vargas não contestou matéria antiditatorial publicada no jornal "Correio da Manhã", o que demonstrava a diminuição do controle e da repressão à imprensa, sinais de uma possível abertura democrática $^{74}$.

Em 1946, o Decreto-lei 8.356 restaurou oficialmente a liberdade de imprensa no Brasil. Em 1953, Vargas, de volta ao poder pelas mãos do

\footnotetext{
${ }^{70}$ FGV. CPDOC. Diretrizes do Estado Novo (1937-1945): Departamento de Imprensa e Propaganda. Disponível em www.cpdoc.fgv.gov.br. Acesso em 06 set. 2010. p.1.

${ }^{71}$ FAGUNDES, Coriolano de Loyola Cabral. Op. Cit. p. 298.

72 "Em 1931 foi criado o Departamento Oficial de Publicidade, e em 1934 o Departamento de Propaganda e Difusão Cultural (DPDC). Já no Estado Novo, no início de 1938, o DPDC transformou-se no Departamento Nacional de Propaganda DNP, que finalmente deu lugar ao DIP”. FGV. CPDOC. Op. cit. p.1.

${ }^{73}$ Ibid. p.1.

${ }^{74}$ FAGUNDES, Coriolano de Loyola Cabral. Op Cit. p. 298.
} 
povo, sancionou a Lei de Imprensa (Lei $\left.n^{\circ} 2.083\right)^{75}$, que viria a ser substituída, durante a ditadura militar, pela lei recentemente revogada pelo Supremo Tribunal Federal ${ }^{76}$.

\subsection{Censura à imprensa na Ditadura Militar}

Em 1965, foi editado o Ato Institucional $n^{\circ} 2$, que elevou para dois anos, a contar da publicação, o prazo de prescrição dos delitos cometidos pela imprensa e dobrou a pena de tais delitos.

Em 1967, foram editadas a nova Lei de Imprensa (Lei 5.250) e a Lei de Segurança Nacional (Decreto-Lei 314), que cominou crimes e sanções para a imprensa. Ainda em 1967, foi promulgada a Constituição, que, apesar de proclamar a liberdade de manifestação do pensamento e a nãocensura, previa, como tratado no Capítulo I, que não seria tolerada a propaganda de guerra, a subversão da ordem ou de preconceitos de raça ou de classe, conceitos abertos que dão margem a qualquer tipo de interpretação.

A Emenda Constitucional $n^{\circ} 1$, de 1969, acrescentou que também não seriam toleradas as manifestações de preconceito religioso e as publicações e exteriorizações contrárias à moral e aos bons costumes, mais uma vez trabalhando com conceitos abertos.

Com o Decreto-lei 1.077 de 1970 o Poder Executivo se aparelhou para censurar a imprensa com base nos argumentos descritos na Constituição de $1967^{77}$, dispondo da seguinte maneira:

Art. $2^{\circ}$ Caberá ao Ministério da Justiça, através do Departamento de Polícia Federal verificar, quando julgar necessário, antes da divulgação de livros e periódicos, a existência de matéria infringente da proibição enunciada no artigo anterior.

\footnotetext{
${ }^{75}$ Ibid. p. 299.

${ }^{76}$ Sobre o assunto conferir: STF, ADPF 130, Rel. Ministro Carlos Britto. Brasília, 30 abr. 2009.

${ }^{77}$ FAGUNDES, Coriolano de Loyola Cabral. Op Cit. p. 329.
} 
Parágrafo único. O Ministro da Justiça fixará, por meio de portaria, o modo e a forma da verificação prevista neste artigo. (grifei)

Seguindo a determinação do Decreto-lei em questão, a Portaria 11-B do Ministério da Justiça disciplinou o modo e a forma de verificação da contrariedade à lei das publicações, o que seria feito pelo Departamento de Polícia Federal, que poderia determinar quando seria necessário o exame prévio bem como a busca e apreensão de todos os exemplares de alguma publicação censurada. De acordo com a Portaria, sujeitava-se à multa aquele que vendesse ou distribuísse obra proibida ou não liberada. Como se vê, com o Decreto-lei 1.077 e a Portaria 11-B do Ministério da Justiça institucionalizou-se a censura prévia no Brasil.

Para o então ministro da justiça, ALFREDO BUZAID, as exteriorizações contrárias à moral e aos bons costumes deveriam ser combatidas com rigor, vez que representavam um mal para a sociedade, admitindo-se, para o seu combate, meios repressivos e também preventivos $^{78}$. Segundo BUZAID, em uma época de combate ao comunismo no Brasil, aqueles que promovessem a subversão da ordem, o preconceito ou os que fizessem publicações imorais seriam inimigos da pátria. Para o governo, era por meio dos periódicos, do rádio e da televisão que o comunismo internacional atuava sobre o povo ${ }^{79}$.

\subsubsection{A censura a posteriori}

A responsabilização ulterior pelos excessos cometidos em publicações tem como objetivo reparar danos causados por essas aos direitos fundamentais ou às garantias constitucionais e legais, como é o caso do segredo de justiça. Como dito linhas acima, o inciso $\mathrm{X}$ do artigo $5^{\circ}$ da Constituição Federal do Brasil assegura o direito a indenização por dano

\footnotetext{
${ }^{78}$ Ibid. p. 330 .

${ }^{79}$ Ibid. p. 333 .
} 
moral ou material à intimidade, à vida privada, à honra e à imagem das pessoas.

A proteção de direitos fundamentais através da condenação de jornalistas e periódicos ao pagamento de indenizações pela sua violação não é nova. O que é recente é a interpretação da doutrina de que tais condenações são forma de censura, enxergando nelas o mesmo efeito inibidor da expressão gerado pela proibição das publicações.

Historicamente, a restrição prévia à expressão sempre foi considerada mais séria e menos tolerável do que as repressões posteriores. Esse era, por exemplo, o posicionamento da Corte Suprema dos Estados Unidos em $1975^{80}$.

Hoje, as liberdades de expressão e imprensa são muito mais amplas do que as concebidas por WiLlian BLACKSTONE, no século XVIII, pois elas implicam na não existência de qualquer forma de repressão da expressão, seja ela anterior ou posterior à publicação.

Assim, para que haja liberdade de imprensa e de expressão não basta que a expressão possa acontecer, é necessário que ela aconteça e não seja reprimida posteriormente. Afinal, as sanções posteriores às publicações acabam por ter impacto para além do efeito concreto que tenham contra quem são aplicadas, pois geram efeito de intimidação de publicações semelhantes à que foi sancionada, o que a doutrina norte-americana chama de chilling effect ou efeito de esfriamento sobre outras expressões ${ }^{81}$.

Contra o argumento de que bastaria a não imposição de restrições prévias às publicações para garantir a livre expressão, alega-se que não é verdade que com as sanções posteriores todo material chegue ao conhecimento público, justamente em função do chilling effect, que gera

\footnotetext{
80 "O que está por trás de todos esses casos é que uma restrição prévia sobre a expressão e a publicação é a infração mais séria e menos tolerável dos direitos da Primeira Emenda. (...)". TOLLER, Fernando M. Op. Cit. p. 52.

${ }^{81}$ Ibid. p.50.
} 
grande inibição à liberdade de expressão e leva inclusive ao fechamento de diversos jornais, em especial os de pequeno porte, que não suportam as elevadas indenizações a que são obrigados a pagar e acabam por encerrar as suas atividades. É o caso, por exemplo, do jornal "Debate", da pequena cidade de Santa Cruz do Prado, no interior de São Paulo, que foi condenado a pagar o valor de $\mathrm{R} \$ 593$ mil de indenização a título de danos morais a um Juiz, valor que corresponde a dois anos e meio do faturamento da empresa e que, segundo seu proprietário, Sérgio Fleury Moraes, representa uma "pena de morte econômica", 82

Nesse sentido, defende FERnANDO M. TOLLER ${ }^{83}$ que as sanções impostas posteriormente às publicações acabam por implicar em efetiva restrição prévia à expressão por parte dos demais jornais, que são inibidos de publicar matérias semelhantes àquelas que tenham sido sancionadas. $\mathrm{O}$ autor chega a comparar as responsabilidades ulteriores às normas penais, pois ambas possuiriam, além de outros, fins preventivos, vez que buscariam evitar futuros comportamentos semelhantes ${ }^{84}$.

De acordo com EDUARDO BERTONI ${ }^{85}$, as sociedades contemporâneas sofrem com o mau da autocensura, que se dá pelo medo da repressão posterior às publicações. Tem-se, assim, “induzido à autocensura através do medo", nas palavras do Desembargador FERNANDO FOCH DE LEMOS ARIGONY DA SILVA, presidente do Fórum Permanente de Direito à Informação, em seminário realizado na Escola de Magistratura do Rio de Janeiro $^{86}$.

\footnotetext{
${ }^{82}$ CADERNO BRASIL. "Jornal terá que pagar R\$ 593 mil para juiz". Folha de São Paulo, São Paulo, p. A10, 26 jun. 2009.

${ }^{83}$ TOLLER, Fernando M. Op. Cit. p. 58.

${ }^{84}$ Ibid. p. 59.

${ }^{85}$ BERTONI, Eduardo Andrés. Op. Cit. p. 83.

${ }^{86}$ Evento Liberdade de Expressão, realizado em 03 de maio de 2010, no auditório da Escola da Magistratura do Estado do Rio de Janeiro (EMERJ).
} 
Esse tipo de censura, segundo BERTONI, é ainda mais difícil de se combater do que a censura prévia, já que é uma forma difusa de repressão em que não há como punir os culpados. ${ }^{87}$

Como se vê, o sistema de responsabilização ulterior acaba por gerar dois efeitos: de um lado, por vezes, torna inviável a continuação do jornal ou periódico condenado, em razão das elevadas indenizações que são obrigados a pagar; de outro, geram autocensura e fazem com que também a expressão por parte de outros jornalistas e periódicos, que a princípio não tinham relação com a condenação judicial, seja inibida pelo medo de consequências semelhantes.

Argumenta-se, na crítica à censura posterior ou ex post facto, ou ainda ulterior, como preferem alguns, que, além do efeito inibidor da expressão que gera, o ressarcimento pecuniário não repõe os direitos atingidos, já que, por vezes, os danos causados por uma publicação falsa podem ser irreparáveis.

Assevera também EDUARDO BERTONI, que se há justificativas para defender a responsabilidade ulterior não há como negar os mesmo motivos para dar razão à censura prévia. ${ }^{88}$

Portanto, em função do efeito intimidatório que possuem as sanções posteriores às publicações, essas devem dar-se somente em situações absolutamente excepcionais.

Dessa forma, faz-se necessário criar critérios e limites objetivos, estabelecendo-se, assim, um meio termo entre a proteção da expressão e a defesa dos demais direitos fundamentais ${ }^{89}$. Afinal há hoje no Brasil um universo de decisões diferentes, tomadas sem parâmetros específicos, em que, por vezes, um mesmo tribunal profere decisões controversas entre si, o que será visto mais detalhadamente nos próximos capítulos.

\footnotetext{
${ }^{87}$ BERTONI, Eduardo Andrés. Op. Cit. p. 84.

${ }^{88}$ Ibid. p. 83.

${ }^{89}$ Ibid. p. 86 .
} 


\subsubsection{Quanto à forma}

\subsubsection{Administrativa}

A censura administrativa, como o próprio nome indica, é a repressão da expressão realizada por agentes do Poder Executivo, seja através de órgãos de polícia ou através de estruturas criadas especificamente para executá-la.

A censura administrativa, em regra, ocorre previamente às publicações. É o caso daquelas realizadas pelo Departamento de Imprensa e Propaganda e pelo Departamento de Polícia Federal, na Era Vargas e durante a ditadura militar, respectivamente.

De acordo com EDUARDO BERTONI, no entanto, a censura administrativa pode dar-se ainda sobre a liberdade de instalação e funcionamento dos meios de comunicação ${ }^{90}$, sobre a qual se refere o Capítulo I acima. Trata-se da outorga de concessão, onde ela é necessária ou seja, nos meios de radiodifusão - a poucas empresas, o que tem se tornado comum em alguns países latino-americanos.

\subsubsection{Judicial}

No Capítulo I, quando se tratou da posição de preferência ocupada pelas liberdades de expressão, imprensa e de informação, viu-se que dela resulta a absoluta excepcionalidade da censura prévia das publicações, que, como se viu, está associada à censura administrativa, reservando-se essa medida aos raros casos em que a composição posterior do dano, que eventualmente seja causado a outros direitos fundamentais, possa vir a ser impossível.

\footnotetext{
${ }^{90}$ Ibid. p. 88.
} 
Sendo assim, na defesa dos direitos fundamentais em face dos exageros cometidos no exercício das liberdades de expressão e imprensa e do direito à informação, cabe, em regra, ao Poder Judiciário impor limites àqueles que violam direitos de outros, ou, como bem assevera GRANDINETTI:

"Qualquer restrição deve ser determinada por ordem judicial, mediante o devido
processo legal. E, mesmo o Poder Judiciário, só deve impor qualquer restrição à
liberdade de expressão quando for imprescindível para salvaguardar outros
direitos que não possam ser protegidos ou compostos de outro modo menos
gravoso."

Em oposição à censura administrativa, a censura judicial, em geral, está associada à censura realizada a posteriori. Apesar disso, a limitação da expressão realizada pelos órgãos do Poder Judiciário pode ser prévia ou posterior.

A censura judicial prévia é um fenômeno recente que tem como objetivo proteger direitos individuais ou evitar a consumação de delitos. ${ }^{92}$

A repressão da expressão pelo Poder Judiciário tem assumido, tanto na doutrina quanto nas próprias decisões judiciais, uma conotação de censura "boa", encarregada da função de tutelar direitos constitucionais individuais, em oposição à chamada "censura tradicional", que se diz imposta pelo Estado em favor de si mesmo. ${ }^{93}$

Há, ainda, quem vá além e defenda que a censura judicial não é censura, uma vez que censura seria apenas a limitação da expressão realizada pelos Poderes Legislativo e Executivo, com base em normas gerais. ${ }^{94}$ MANUEL AlCEU AFFONSO FERREIRA, ao contrário, assevera que

\footnotetext{
${ }^{91}$ CARVAlHO, Luís Gustavo Grandinetti Castanho de. Direito de informação e liberdade de expressão. Op. Cit. p. 51.

${ }_{92}$ SAGÜES, Néstor Pedro. Censura judicial previa a la prensa: Posición de La Corte Interamericana de Derechos Humanos. In: Anuário de Derecho Constitucional Latinoamericano, 2006. p. 965.

${ }^{93}$ Ibid. p. 966.

${ }^{94}$ Ibid. p. 967.
} 
"ofende a Constituição a censura oriunda de qualquer um dos Poderes"95. Para ele, qualquer restrição à emissão da opinião deve ser encarada como inconstitucionalidade ${ }^{96}$.

\subsection{Há uma maneira melhor de restringir liberdades?}

As Convenções americana e européia de direitos humanos diferem na forma de censura que admitem. A primeira proíbe, em seu artigo 13, tanto a censura prévia quanto as responsabilizações ulteriores, corroborando a ideia acima exposta de que ambas acabam por ter o mesmo efeito inibidor da expressão, admitindo apenas a censura prévia de espetáculos públicos para a proteção moral da infância e da adolescência. Já a Convenção Européia admite, no artigo 10, que o exercício da liberdade de opinião e do direito de informar poderá ser submetido a certas formalidades e restrições prévias ou sanções a posteriori, para garantir a manutenção da segurança nacional, da integridade territorial, da segurança pública, da ordem, da prevenção do delito, da proteção da saúde e da moral, dentre outros motivos. ${ }^{97}$

A Convenção Européia traz ainda mais uma motivação para a censura ou para a sanção de publicações que deve ser destacada pela importância que tem para este trabalho. Trata-se das restrições impostas às publicações em função da garantia da autoridade e da imparcialidade das decisões judiciais.

Nesse sentido, decidiu a Câmara dos Lordes inglesa pela proibição da publicação, no renomado jornal "Sunday Times", em 1979, do "caso talidomida", remédio supostamente com efeitos sedativos, sustentando que, por tratar-se de caso sub judice, a reportagem poderia prejudicar a

\footnotetext{
${ }^{95}$ FERREIRA, Manuel Alceu Affonso. Censura Legislada. In: Revista do Advogado. Ano XXX. no 109, ago. 2010. Associação dos Advogados de São Paulo. p. 77.

${ }^{96}$ Ibid. p. 75.

${ }^{97}$ BELLUSCIO, Augusto César. La Censura Judicial. In: Anuário de Derecho Constitucional Latinoamericano, 2006. p. 953.
} 
imparcialidade da decisão, já que o tribunal poderia sentir-se pressionado pela publicação em questão. A decisão foi posteriormente reformada pela Corte européia de Direitos Humanos, sob a alegação de que o caso não se enquadrava nos requisitos do artigo 10 da Convenção, uma vez que o assunto era de conhecimento público e, portanto, não haveria perigo à imparcialidade da Justiça ${ }^{98}$.

No Brasil, como será visto mais adiante, apesar da ausência de previsão da censura, seja ela prévia ou posterior, em razão da necessidade de garantir a imparcialidade das decisões judiciais ou mesmo o segredo de justiça, essa tem acontecido com muita frequência.

O Brasil, aliás, hoje não se encontra em boa posição na defesa da liberdade de expressão. De acordo com a ONG francesa "Repórteres Sem Fronteiras", no ranking mundial da liberdade de imprensa, que conta com cento e setenta e cinco países, o Brasil ocupa o $71^{\circ}$ lugar da lista e é classificado como país em que há problemas sensíveis para a liberdade de expressão. Dividem a primeira colocação dessa lista Dinamarca, Finlândia, Irlanda, Noruega e Suécia, em que, segundo a ONG, não há ameaças às liberdades de expressão e imprensa ${ }^{99}$.

Também na classificação do grau de liberdade de imprensa realizado pela ONG norte-americana "Freedom House", o Brasil não está em posição favorável, sendo classificado como parcialmente livre ${ }^{100}$.

Aqui, o problema é mais grave no que se refere à censura judicial à expressão. É o Poder Judiciário que constitui a principal ameaça à liberdade de expressão no Brasil. De acordo com dados de levantamento realizado pela Revista “Consultor Jurídico”, em 2007, o Brasil é o país do mundo em

\footnotetext{
${ }^{98}$ Ibid. p. 955.

${ }^{99}$ Disponível em <http://en.rsf.org/spip.php?page=classement\&id_rubrique=1001〉. Acesso em 10 set. 2010.

${ }^{100}$ SILVA, Carlos Eduardo Lins. Censura Judicial à Imprensa no Brasil: Autorregulação e maturidade democrática. In: Ensaios do Instituto de Estudos Econômicos e Internacionais (UNESP). São Paulo, 2010. Disponível em http://www.ieei-unesp.com.br. Acesso em 01 set. 2010. p. 05 .
} 
que mais se processam jornalistas. As intimidações dos jornalistas decorrem, em grande parte das vezes, de sentenças de primeira instância ${ }^{101}$, que, embora possam ser - e sejam de fato em $80 \%$ das vezes, de acordo com dados da ONG Artigo $19^{102}$ - revistas por tribunais superiores, acabam por promover a autocensura dos meios de comunicação, até porque tais reformas podem levar anos para acontecer.

Criou-se, assim, uma indústria de indenizações por danos morais ${ }^{103}$, que põe em risco a existência das liberdades de expressão e imprensa no Brasil.

\footnotetext{
${ }^{101}$ Disponível em <http://www.conjur.com.br/2007-mai31/aumenta_valor_medio_indenizacoes_imprensa>. Acesso em 30 ago. 2010. ${ }^{102}$ SILVA, Carlos Eduardo Lins. Op. Cit. p. 11.

${ }^{103}$ NAVES, Nelson Vital. Relações entre a Imprensa e a Justiça no Brasil. Disponível em http://bdjur.stj.gov.br. Acesso em 10 set. 2010. p. 1.
} 


\section{A INFLUÊNCIA DOS MEIOS DE COMUNICAÇÃO SOBRE O PODER JUDICIÁRIO E OS LIMITES IMPOSTOS POR ESSE ÀQUELES}

Depois de tratar das liberdades de expressão, imprensa, comunicação, do direito à informação e das espécies de restrições eventualmente impostas a eles, tratar-se-á agora das relações entre os meios de comunicação e o Poder Judiciário, em especial, da influência que os primeiros exercem sobre o segundo. Com isso, será possível analisar, no capítulo seguinte, alguns exemplos das limitações impostas pelo Poder Judiciário aos veículos de comunicação, com objetivo de reduzir ou eliminar tal influência.

Neste Capítulo utilizou-se como referência da influência dos meios de comunicação sobre o Poder Judiciário o tratamento conferido pela imprensa aos crimes, investigações e processos criminais, tendo em vista serem esses os que mais espaço ocupam nos noticiários, já que são eles os que parecem atrair o maior interesse da população.

\subsection{O jornalismo investigativo e o "denuncismo"}

O jornalismo de investigação, na lição de JUAN JORGE FAUNDES, tem como objeto a busca pela informação oculta e pelas fontes secretas ${ }^{104}$. O exercício da investigação pelos jornalistas pressupõe, portanto, a assunção, pela imprensa, de tarefas reservadas à polícia e ao Poder Judiciário.

Uma das funções do jornalista é denunciar as questões que investiga. Essa ideia está presente no Código de Ética do Jornalista, aprovado no Congresso de Jornalistas, realizado em 1985, no Rio de Janeiro, e alterado em São Paulo, no ano seguinte, no XXI Congresso Nacional dos Jornalistas

\footnotetext{
${ }^{104}$ FAUNDES, Juan Jorge. Ética y contexto Del periodismo de investigación. Sala de Prensa Web para professionales de la comunicación iberoamericanos, ano IV, v. 2, nº 43, 2002. Disponível em <www.saladeprensa.org/art274.htm>. Acesso em 01 out. 2010. p.1.
} 
Profissionais. Diz o artigo $9^{\circ}$ do referido Código que são deveres do jornalista “(...) divulgar todos os fatos que sejam de interesse público (...) [e] combater e denunciar todas as formas de corrupção, em especial quando exercida com objetivo de controlar a informação" 105.

KARL MARX, já em 1849, quando da sua defesa na acusação de difamação contra funcionários do governo no jornal Neue Rheinische Zeitung, da qual foi absolvido, já se referia ao dever de denunciar do jornalista $^{106}$.

Além do dever de denunciar, o jornalista tem também o compromisso com a verdade dos fatos, devendo apurar com precisão os acontecimentos que pretende narrar ${ }^{107}$, como determina o artigo $7^{\circ}$ do já citado Código de Ética do Jornalista. Para tanto, o jornalista deve sempre ouvir todos os personagens envolvidos na história a ser contada.

Para Luís GuSTAVO GRANDINETTI, a sofisticação dos meios de comunicação de massa e o alto custo dos equipamentos necessários para pôr em funcionamento veículos de imprensa acabam por gerar a monopolização da informação, o que torna, segundo ele, mais exigível ainda o respeito ao dever de veracidade das informações ${ }^{108}$, de modo que a informação não se confunda com manipulação.

Esclareça-se, no entanto, que o dever de veracidade, a despeito de opiniões em sentido contrário $^{109}$, não implica na obrigação de imparcialidade dos jornalistas, ou seja, o fato de se ter que buscar e publicar a versão mais próxima da realidade não significa que não se possa opinar sobre os fatos narrados. Nesse sentido já decidiu a Suprema Corte dos

\footnotetext{
${ }^{105}$ SANTOS, Reinaldo. A Ética na Comunicação (Textos dos Códigos). $2^{\mathrm{a}}$ ed. Rio de Janeiro: Destaque, 1996. p. 6.

${ }^{106}$ MARX, Karl. Liberdade de Imprensa. Tradução: Cláudia Schilling e José Fonseca. Porto Alegre: L\&PM, 2010. p. 104.

${ }_{107}$ SANTOS, Reinaldo. Op. Cit. p. 6.

${ }^{108}$ CARVALHO, Luís Gustavo Grandinetti Castanho de. Liberdade de informação e o direito difuso à informação verdadeira. Op. Cit. p. 56

109 "A verdade, por seu turno, contrapõe-se à inevitável subjetividade do jornalista". ANDRADE, Fábio Martins de. Mídia e Poder Judiciário: A influência dos órgãos da mídia no processo penal brasileiro. Rio de Janeiro: Lúmen Júris, 2007. p. 96.
} 
Estados Unidos, no caso New York Times vs. Sullivan, em que se determinou que as opiniões ofensivas publicadas pela imprensa não geram direito a indenização, a menos que a elas se some conhecimento da falsidade ou a absoluta despreocupação de averiguar sua veracidade ${ }^{110}$. No Brasil, em interessante decisão, a juíza ANA PAULA THEODOSIO DE Carvalho, da $5^{\text {a }}$ Vara Cível de São José dos Campos, asseverou que, apesar de ter o dever de expor todos os lados de uma notícia, a imprensa tem o direito de escolher o enfoque que dará às suas reportagens, o que, segundo ela, é uma circunstância natural e admissível legalmente ${ }^{111}$.

Ocorre que os dois deveres supra descritos, em diversos casos, entram em conflito, ou melhor, impossibilitam o exercício um do outro. Isso porque, quando no exercício do jornalismo investigativo ou do dever de denunciar, o jornalista tem pressa e deseja sempre divulgar a notícia antes que outros veículos o façam. Assim, na busca pelo chamado "furo", é necessário ter uma rapidez que é incompatível com a precisão, o que faz com que, muitas vezes, as notícias forneçam versões apressadas da realidade e levem a prejulgamentos, contrariando o princípio da presunção de inocência, como veremos, e levando a população e, em certos casos, também os juízes ou jurados, a acreditarem em tal versão como se verdade fosse.

Ademais, o jornalismo investigativo, segundo FÁBIO MARTINS DE ANDRADE, tem preferência pelas notícias sobre crimes e pela versão oficial, acusatória desses. É a consagração do "denuncismo", segundo o autor ${ }^{112}$. Isso se deve ao fato de que os argumentos de acusação, em geral, são os que encontram maior respaldo na sociedade. ${ }^{113}$

\footnotetext{
${ }^{110}$ CARVALHO, Luís Gustavo Grandinetti Castanho de. Liberdade de informação e o direito difuso à informação verdadeira. Op. Cit. p. 59.

$5^{\text {a }}$ Vara Cível de São José dos Campos. Processo no 577.09.406140-9. Juíza Ana Paula Theodosio de Carvalho. São José dos Campos, 21 set. 2010.

112 ANDRADE, Fábio Martins de. Op. Cit. p. 261

113 BUDÓ, Marília Denardin. O jornalismo e os julgamentos: uma abordagem acerca da possibilidade de influência da mídia em decisões judiciais. Disponível em
} 
Assim, apesar da relevante função preventiva do jornalismo investigativo, sem a qual alguns crimes permaneceriam sem serem descobertos ou desvendados ${ }^{114}$, algumas notícias podem repercutir negativamente sobre as investigações e sobre as decisões judiciais. Nas palavras de J.N. CUNHA RODRIGUES:

“(...) o material jornalístico fornece abundantes sugestões para a investigação (...) em contrapartida, pode provocar erros ou desvios, seja por intenção deliberada de quem vinculou os fatos, seja pelo modo como a mensagem foi elaborada (...), [que] podem levar à publicação de notícias que repercutem negativamente na investigação." 115

A juíza LuCiana NovaKoski FerReira Alves De OliveirA, da $2^{\mathrm{a}}$ Vara Cível de São Paulo, ao proferir decisão favorável à revista "Veja", negando o pedido de indenização por danos morais feito por Fábio Luís Lula da Silva, ressaltou que não é exigido do jornalista o mesmo rigor e aprofundamento das provas que devem ter as autoridades policiais e judiciais, sob pena de inviabilizar o jornalismo investigativo. Entretanto, segundo a juíza, isso não isenta o jornalista do dever de veracidade e de diligência na apuração do caso, a fim de evitar que a divulgação precipitada dos fatos possa arruinar a vida dos retratados na notícia ${ }^{116}$.

Para o Ministro do Superior Tribunal de Justiça, NILSON VITAL NAVES, é preciso evitar que a utilidade da imprensa investigativa possa ser prejudicada pelas armadilhas nas quais o jornalista pode cair, permitindo que a notícia transcenda a apuração e a divulgação dos fatos, invadindo o terreno do Poder Judiciário e levando a erro a opinião pública ${ }^{117}$.

<http://www.intercom.org.br/papers/nacionais/2005/resumos/R1213-1.pdf >. Acesso em 22 set. 2010. p. 04.

${ }_{114}$ PLAYFAIR, Giles; SINGTON, Derrick. Apud. ANDRADE, Fábio Martins de. Op. Cit. p. 267.

${ }^{115}$ RODRIGUES, J.N. Cunha. Justiça e Comunicação Social. In: Revista portuguesa de ciência criminal. A.7, no4 (Out.-Dez. 1997). p.565.

${ }^{116} 2^{\mathrm{a}}$ Vara Cível de São Paulo. Processo no 011.06.119805-8. Juíza Luciana Novakoski Ferreira Alves de Oliveira. São Paulo, 17 set. 2010.

${ }^{117}$ NAVES, Nelson Vital. Op. Cit. p. 04. 


\subsection{A ofensa ao princípio da presunção de inocência}

Dispõe o inciso LVII do artigo $5^{\circ}$ da Constituição Federal de 1988 que "ninguém será considerado culpado até o trânsito em julgado de sentença penal condenatória".

Para LUIS FLÁvio GOMES, o fato de a imprensa noticiar um crime desde os primeiros momentos de uma investigação criminal, divulgando nomes de suspeitos, prejudicando sua imagem e honra, contraria frontalmente o princípio da presunção de inocência ${ }^{118}$.

NELSON Vital NAVES lembra, ainda, que na imprensa a absolvição de uma pessoa considerada culpada mesmo antes da instauração do processo, é sinal de impunidade, apesar de essa decorrer, em grande parte das vezes, da ausência de provas concretas da responsabilidade penal. Para o Ministro, o "denuncismo" da imprensa tem, em alguns casos, condenado inocentes ${ }^{119}$.

Como dito, a imprensa, em regra, se aproxima da versão acusatória e divulga fatos e nomes como se já estivessem provados, com força de sentença definitiva perante a opinião pública ${ }^{120}$. A mídia tende a gerar uma estigmatização do acusado como bandido, "condenando-o" antes da sentença, o que, para alguns, parece ferir o princípio da presunção de inocência ${ }^{121}$.

Em que pesem os argumentos aqui apresentados, o princípio da presunção de inocência não parece ser passível de ofensa pela imprensa, tendo em vista que tal princípio é direcionado aos Poderes do Estado,

\footnotetext{
118 GOMES, Luiz Flávio. Liberdade de imprensa, investigação criminal e respeito à pessoa: Estudos de direito penal e processual penal. São Paulo: Revista dos Tribunais, 1998. p. 288.

${ }^{119}$ NAVES, Nelson Vital. Op. Cit. p. 04.

${ }^{120}$ SERRÃO, Osvaldo. Segurança Pública, Imprensa e Direitos Individuais. Boletim do IBCCrim. São Paulo, nº 57, ago. 1997. p.08.

${ }^{121}$ DOMINGUEZ, Daniela Montenegro Mota. A influência da Mídia nas decisões do Juiz penal. Disponível em 〈http://www.revistas.unifacs.br/index.php/redu/article/view/507〉. Acesso em 02 out. 2010.
} 
constituindo limitação desses, e que a condenação a que se refere a Constituição não é a condenação social e midiática, mas a judicial.

No entanto, a preservação do direito a não ser considerado culpado salvo por sentença transitada em julgado e de outros direitos fundamentais, como a honra, a imagem e a intimidade, têm sido usados, pelo Poder Judiciário, como argumento para proibir a imprensa de manifestar-se sobre casos sub judice ou ainda sob investigação policial ou administrativa, o que será visto com mais detalhes no Capítulo IV.

\subsection{Segredo de justiça}

"Qualquer tipo de censura Deve ser abominado E o segredo de justiça É um dos tipos velado Porque proíbe a notícia

Dos casos até de polícia De modo despudorado" 122

O constituinte de 1988, mais uma vez privilegiando a democracia, optou expressamente, nos artigos $5^{\circ}, \mathrm{LX}, 37$, caput, e 93, IX e X, pela publicidade no âmbito dos processos administrativos e judiciais. O objetivo último da publicidade é a garantia da democracia, já que essa visa facilitar o controle sobre as decisões judiciais e coibir os excessos que possam ser cometidos pelo Poder Judiciário.

Excepcionalmente, no entanto, a Constituição admite que a lei possa restringir a publicidade dos atos processuais - e também preprocessuais, por interpretação, permitindo que tramitem em segredo de justiça, sempre que o exigir o interesse público ou a preservação da intimidade. Assim, o Código de Processo Civil, em seu artigo 155, previu as exceções à publicidade nos casos admitidos na Constituição Federal. Também o artigo 20 do Código de Processo Penal, obedecendo ao disposto na Constituição, recomenda o

\footnotetext{
${ }^{122}$ NASSIF, Luis. O segredo de justiça. Disponível em <http://luisnassifonline.blog.uol.com.br/>.
} Acesso em 10 out. 2010. 
sigilo na fase preprocessual, durante as investigações policiais que levarão à conclusão do inquérito.

Esclareça-se, no entanto, que o segredo de justiça refere-se tãosomente aos atos do processo e não à sua própria existência, que será sempre pública $^{123}$. E refere-se, ainda, a terceiros, ou melhor, as partes e seus advogados deverão sempre ter amplo acesso aos autos do processo e a todos os procedimentos judiciais. Incluem-se entre os terceiros afetados pelo segredo de justiça, os meios de comunicação.

A princípio, a liberdade de imprensa não é limitada pelo segredo de justiça, tendo em vista que a própria Constituição Federal previu expressa e taxativamente os limites impostos a ela, no inciso $\mathrm{X}$ do artigo $5^{\mathrm{o}}{ }^{124}$. O Superior Tribunal de Justiça, no entanto, diverge sobre o assunto, tendo julgados em ambos os sentidos ${ }^{125}$. O Tribunal de Justiça do Rio Grande do Sul, em interessante julgado, apesar de contrário à liberdade de imprensa, traça importantes distinções, a seguir destacadas:

(...) uma coisa é a publicidade do fato; outra coisa é a publicidade do inquérito policial ou do processo; (...) Em suma: uma coisa é a publicidade do inquérito ou do processo, acessível a qualquer pessoa, outra, bem diferente, é a divulgação na imprensa dos fatos constantes do inquérito ou do processo. ${ }^{126}$

Luiz MANOEl G. JÚNIOR, JuSSARA FERREIRA e MiRIAM ChUEIRI, apesar de entenderem que o segredo de justiça é sim uma limitação constitucional da liberdade de imprensa, entendem que a existência do segredo de justiça não pode impedir que a imprensa realize suas próprias

\footnotetext{
123 ARAGÃO, Egas Dirceu Moniz de. Comentários ao Código de Processo Civil. v. II. Rio de Janeiro: Forense, 1998. p. 16.

${ }^{124}$ CHUEIRI, Miriam Fecchio; FERREIRA, Jussara Suzi Assis Borges Nasser; JUNIOR, Luis Manoel Gomes. Segredo de Justiça: Aspectos processuais controvertidos e liberdade de imprensa. Disponível <http://www.fafibe.br/revistasonline/arquivos/revistajuridicafafibe/sumario/5/14042010170941.pd f>. Acesso em 05 out. 2010. p. 13.

${ }^{125}$ Conferir: STJ, RMS no 3292-PR, Rel. Ministro Costa Leite. Brasília, 04 abr.1995 e, em sentido oposto STJ, RMS no 398-MG, Rel. Ministro Fontes Alencar. Brasília, 16 mar. 1992 - DU 03.08.1992.

${ }^{126}$ TJRS, Apelação Cível no 70007346398 , Rel. Desembargador Adão Sérgio do Nascimento Cassiano. Porto Alegre, 22 mar. 2006.
} 
investigações sobre o caso em julgamento ${ }^{127}$. Acrescente-se, ainda, que o segredo de justiça não pode impedir que a imprensa expresse sua opinião sobre os fatos investigados em sede policial ou judicial. Nesse sentido, afirma JONATAS E. M. MACHADO que "o segredo de justiça não pode ser sobreinterpretado de forma a ter um efeito irradiante para o âmbito extraprocessual" 128. A impossibilidade de abertura irrestrita dos autos, portanto, não deve impedir o trabalho investigativo da imprensa.

Para HENRIQUE J. ASSEJO, o fundamento do segredo de justiça é garantia da investigação, de modo a evitar "que o culpado conheça as pistas de instrução e possa frustrá-las" ${ }^{129}$. Da mesma forma, entende o Ministro CELso DE MELlo, do Supremo Tribunal Federal, que os jornalistas não são os destinatários do sigilo imposto aos processos que tramitam em segredo de justiça, já que, se assim fosse, o governo não teria encaminhado ao Congresso Nacional projeto de lei ${ }^{130}$ com a intenção de que o sigilo os $\operatorname{atinja}^{131}$.

Para o também Ministro do STF MARCo Aurélio MELlO em entrevista ao jornal "O Estado de S. Paulo", o que se deve combater é o vazamento de informações que estão sob segredo de justiça e não o veículo de comunicação que posteriormente publica as informações vazadas. Diz o Ministro: "Combata-se o vazamento, mas sem chegar ao cerceio da liberdade de expressão e de veicular notícias" ${ }^{132}$. Esse foi também o

\footnotetext{
${ }^{127}$ CHUEIRI, Miriam Fecchio; FERREIRA, Jussara Suzi Assis Borges Nasser; JUNIOR, Luis Manoel Gomes. Op. Cit. p. 18.

${ }^{128}$ MACHADO, Jonatas E. M. Liberdade de Expressão. Coimbra: Almedina, 2002. p. 568.

${ }^{129}$ ASSEJO, Henrique J. Concepcion Técnico Jurídica de La Instruccion Criminal. In: Revista de Derecho Procesal no 4. p. 876.

${ }^{130}$ Trata-se do Projeto de Lei no 2.961/97, conhecido com "Lei da Mordaça", que proíbe delegados de polícia, funcionários administrativos, promotores de Justiça, procuradores e juízes de fornecer à imprensa informações sobre investigações, inquéritos ou processos ou, ainda, permitir que cheguem a conhecimento de terceiros fatos ou informações contidas em investigações ou processos judiciais. O projeto foi aprovado na Câmara dos Deputados em 2001 e atualmente tramita no Senado Federal.

${ }^{131}$ REZENDE, Jorge. Segredo de Justiça, liberdade de imprensa e moralidade. Disponível em < http://www.paraibanews.com/2008/04/07/segredo-de-justica-liberdade-de-imprensa-emoralidade/>. Acesso em 30 set. 2010.

${ }^{132}$ MACEDO, Fausto. "Vazamento é antecedente, não é erro do jornal", diz Marco Aurélio. $O$ Estado de S. Paulo. São Paulo, 15 ago. 2009. Disponível em <
} 
entendimento da Suprema Corte dos Estados Unidos no julgamento do caso conhecido como "Documentos do Pentágono", em que saíram vitoriosos o jornal "The New York Times" e outros, entendendo a Corte que esses não deveriam ser responsabilizados pelo roubo dos documentos sigilosos, tendo em vista que o vazamento das informações fora proporcionado por um funcionário do Departamento de Defesa ${ }^{133}$. Assim, tem prevalecido na jurisprudência, nacional e estrangeira, a idéia de que não se deve responsabilizar os veículos de comunicação por divulgarem informações por eles obtidas, ainda que tais informações fossem sigilosas, tendo em vista que não são os jornalistas os responsáveis pela violação do sigilo e que a publicação obedece ao dever de informar.

\subsection{A imparcialidade dos julgadores e a influência das notícias nas decisões judiciais, em especial, as criminais}

\subsubsection{O princípio da imparcialidade}

O princípio da imparcialidade do Juiz, apesar de não estar expresso na Constituição Federal, decorre, segundo a doutrina, do princípio do juiz natural, previsto nos incisos XXXVII e LIII da Carta Magna, e das prerrogativas reconhecidas aos magistrados, de forma a garantir o exercício pleno de suas funções. De acordo com esse princípio, o Juiz, pessoa física ocupante do cargo de magistrado, deve ser indiferente em relação ao litígio, à sorte do julgamento e ao destino de todos aqueles que, direta ou indiretamente, estejam nele envolvidos ${ }^{134}$.

O Código de Processo Civil prevê, nos artigos 134 e 135, os instrumentos de garantia da imparcialidade do Juiz, buscando evitar que o

http://www.estadao.com.br/estadaodehoje/20090815/not_imp419227,0.php>. Acesso em 13 set. 2010.

${ }^{133}$ SILVA, Carlos Eduardo Lins. Op. Cit. p. 21.

${ }^{134}$ BUENO, Cássio Scarpinella. Curso Sistematizado de Direito Processual Civil: Teoria Geral do Direito Processual Civil. v. 1. São Paulo: Saraiva, 2007. p, 117. 
magistrado tenha qualquer interesse direto e pessoal na demanda que deve julgar.

\subsubsection{Opinião pública}

No Capítulo I, quando se tratou do direito à informação, foi dito que os meios de comunicação hoje ocupam a posição de "Quarto Poder" da República, na medida em que exercem vigilância sobre os poderes constituídos e que possuem grande influência sobre a opinião pública, apesar de carecerem de legitimidade, por não possuírem representatividade, na medida em que não são eleitos, e por não sofrerem qualquer tipo de controle ou fiscalização ${ }^{135}$.

Para que se possa entender a influência provocada pelos veículos de comunicação sobre a sociedade, de forma tal que os torna, de acordo com alguns doutrinadores, o "Quarto Poder", é necessário esclarecer primeiramente o que se entende por opinião pública e qual a importância dessa para as decisões judiciais.

Na concepção de JÜRGEN HABERMAS, a chamada "opinião pública" está em parte decomposta em opiniões de pessoas privadas e em parte concentrada em opiniões formais de instituições jornalísticas ativas ${ }^{136}$. Etimologicamente, o termo "opinião" significa juízo sem certeza, ideia não verificada ou sem fundamento ${ }^{137}$. O conceito de opinião pública é, no entanto, de acordo com FÁBIO MARTINS DE ANDRADE, mais abrangente e pode ser definido como o "(...) juízo coletivo adotado e exteriorizado no mesmo direcionamento por um grupo de pessoas com expressiva representatividade popular sobre algo de interesse geral" ${ }^{138}$. Para ROBERTO AMARAL, em uma obra dedicada ao estudo do poder da imprensa sobre a

\footnotetext{
${ }^{135}$ ANDRADE, Fábio Martins de. Op. Cit. p. 79.

${ }^{136}$ HABERMAS, Jürgen. Mudança Estrutural da Esfera Pública: Investigações quanto a uma categoria da sociedade burguesa. Tradução: Flávio R. Kothe. Rio de Janeiro: Tempo Brasileiro, 1984. p. 287.

${ }^{137}$ ANDRADE, Fábio Martins de. Op. Cit. p. 43.

${ }^{138}$ Ibid. p. 45.
} 
opinião pública, a imprensa hoje se distancia da sua função inicial, meramente informativa, passando a opinar mais do que noticiar, formando opiniões. Assim, entende o autor que a opinião pública hoje se confunde com a opinião publicada ${ }^{139}$.

\subsubsection{A influência das notícias sobre opinião pública e sobre os membros Poder Judiciário}

A falta de cultura jurídica da sociedade e a ânsia pela redução da violência e da corrupção fazem com que os leigos acatem o discurso oficial acusatório, e os meios de comunicação, para satisfazer os desejos dos seus consumidores, acabam por promover verdadeiros "linchamentos" dos acusados da prática de crimes ainda sob investigação policial ou judicial.

Assim, quando se trata de noticiar crimes, os meios de comunicação e também a sociedade, de forma geral, identificam-se com a versão acusatória do processo criminal e, portanto, a opinião pública, na concepção acima expressa, tende a pressionar os juízes e julgadores de todo o tipo a optar pela condenação dos acusados do cometimento dos crimes noticiados.

Apesar de orientados pelo princípio da imparcialidade, os juízes, antes de serem membros do Poder Judiciário, fazem parte da sociedade e, como tal, sofrem a influência das estigmatizações e dos prejulgamentos realizados pelos veículos de comunicação, no exercício da sua função de denunciar ou do jornalismo investigativo, sobre os quais se falou acima.

Assim, a imprensa gera grande influência sobre a sociedade e sobre os juízes, togados ou leigos, que dela fazem parte, influindo na sua atividade profissional, direta ou indiretamente, e desvirtuando o processo judicial. Esse efeito é mais facilmente percebido no Tribunal do Júri, tendo

\footnotetext{
${ }^{139}$ AMARAL, Roberto. Imprensa e Controle da Opinião Pública: Informação e Representação no Mundo Globalizado. Disponível em http://www.rblinux.com.br/rogeriobarreto/mesuneb/Roberto_Amarval.pdf $>$. Acesso em 10 out. 2010. p. 134.
} 
em vista tratar-se de um órgão jurisdicional composto por leigos e que, portanto, carece de informação técnica.

Anote-se também que a influência não se dá apenas na decisão final, mas também nas decisões proferidas no curso do processo, a exemplo da decretação da prisão preventiva, que, muitas vezes, se dá com base no clamor público do caso, o que contraria frontalmente os fundamentos para a mesma, previstos no artigo 312 do Código de Processo Penal ${ }^{140}$. Sobre o assunto já se manifestou o Supremo Tribunal Federal no sentido de que o fato de o delito provocar grande repercussão nos veículos de comunicação não deve conduzir à prisão preventiva do acusado ${ }^{141}$.

\subsubsection{O Trial by the Media ${ }^{142}$}

Os prejulgamentos realizados pela mídia são conhecidos pela doutrina norte-americana como "Trial by the Media" ${ }^{143}$. Nos Estados Unidos os meios de comunicação têm papel relevante na influência do Júri e é amplo o debate sobre os efeitos negativos dessa influência.

O problema do "Trial by the media", portanto, não é novo e nem é só brasileiro. No entanto, tem atraído recentemente maiores atenções em função das consequências que tem gerado, ou seja, em razão das limitações impostas pelo Poder Judiciário aos meios de comunicação, na tentativa de minorar os efeitos dos prejulgamentos realizados por esses.

Apesar de o problema não ser novo, a influência das notícias veiculadas nos meios de comunicação sobre o Poder Judiciário é hoje muito maior do que no passado, haja vista a velocidade da disseminação das informações e o alcance delas proporcionado pela internet e pelas novas mídias.

\footnotetext{
${ }^{140}$ BUDÓ, Marília Denardin. Op. Cit. p. 07.

${ }^{141}$ STF, HC 83728/RS. Rel. Ministro Marco Aurélio. Brasília, 17 fev. 2004.

142 Expressão em inglês que designa "Julgamento pela mídia".

143 ANDRADE. Fábio Martins de. Op. Cit. p. 295.
} 


\subsubsection{As tentativas de evitar o prejulgamento pela mídia}

O Poder Judiciário é, de acordo com o artigo $5^{\circ}$, inciso XXXV, a única instância legítima para a reparação das violações jurídicas. Por outro lado, os meios de comunicação têm o direito de narrar os fatos do ponto de vista que melhor lhes convém. Vê-se, portanto, a dificuldade em se estabelecer limites à influência do Poder Judiciário pelos meios de comunicação, seja pela pressão exercida pela imprensa ou diretamente pela pressão exercida pela sociedade, sem, contudo, cercear as liberdades de imprensa e expressão.

A jurisprudência brasileira tem divergido sobre a necessidade de controle das opiniões jornalísticas, ora sendo favorável a esse, entendendo que dado o grande poder dos meios de comunicação devem eles ter cuidado com as opiniões que publicam, ora atribuindo ao leitor a obrigação de discernir o que é fato e o que é opinião.

Em uma decisão na qual a rádio "Eldorado" foi condenada em processo movido por Tarso Genro, então prefeito de Porto Alegre, a juíza Vivian WiPTli Zanelli, da $33^{\mathrm{a}}$ Vara Cível de São Paulo, define que a liberdade de expressão não pode dispensar o controle ético, já que está em jogo a formação de opiniões em grande escala e não apenas a mera transmissão de fatos e ideias, tendo em vista, nas palavras da juíza, "o poder absoluto dos meios de comunicação de massa" ${ }^{\text {144 }}$.

Já em interessante e recente julgado do Tribunal de Justiça do Distrito Federal, no qual se decidiu favoravelmente a um jornalista em face de um investigado da polícia federal, que o acusava de calúnia, injúria e difamação, um dos magistrados reconhece que o leitor da notícia tem que se acautelar para não fazer da notícia uma verdade absoluta. E, diz o julgador,

\footnotetext{
$14433^{\text {a }}$ Vara Cível de São Paulo, Processo no 000.99.063777-8. Juíza Vivian Wiptli Zanelli. São Paulo, 27 mai. 2001.
} 
o mesmo cuidado devem ter os juízes. Afinal, segundo ele, se o jornalista não pudesse assumir o risco do erro, não haveria notícia ${ }^{145}$.

\subsection{Choque entre direitos fundamentais}

\subsubsection{Liberdades de expressão, imprensa, comunicação e direito à informação versus direitos da personalidade}

Do acima exposto, extrai-se a dificuldade de se encontrar um ponto de equilíbrio entre a liberdade dos veículos de comunicação e os direitos da personalidade dos cidadãos objeto da publicação.

De um lado, juristas e membros do Poder Judiciário alegam que a divulgação de fatos sob investigação e sob segredo de justiça constitui abuso do direito de informar, prejudicando o bom andamento dos processos e a imparcialidade dos julgadores. Do outro lado, os jornalistas e veículos de comunicação defendem que existe uso abusivo da solução constitucional que prevê a responsabilização ulterior daquele que, ao expressar-se, fere outros direitos fundamentais. As críticas dos comunicadores e dos meios de comunicação ao Poder Judiciário têm se tornado mais severas, em razão dos recentes casos de censura judicial prévia à imprensa, cujo fundamento, em regra, é a tentativa de evitar que se consumem danos aos direitos da personalidade.

O dilema neste capítulo narrado é mais um exemplo do conhecido conflito entre as liberdades de expressão, imprensa, comunicação e de informação, das quais se tratou longamente no Capítulo I acima, e os direitos da personalidade, ou seja, os direitos à intimidade, à vida privada, à

\footnotetext{
145 "Operação Navalha: TJ/DF absolve jornalista acusado pelos crimes de calúnia, injúria e difamação". o_pelos_crimes_de_calunia_injuria_e_difamacao.html>. Acesso em 02 de out. 2010.
} 
honra e à imagem, que constituem limites expressos àquelas liberdades, de acordo com o $\$ 1^{\circ}$ do artigo 220 da Constituição Federal.

Afinal, quando os meios de comunicação noticiam fatos ainda não provados pela polícia e pelo Poder Judiciário, quando informam sobre processos que tramitam sob segredo de justiça e quando influenciam julgadores com os prejulgamentos publicados, por vezes, acabam por ferir os direitos constitucionais à intimidade, à vida privada, à honra e à imagem, bem como o direito, daquele que é retratado nas notícias, a ser julgado por um Juiz imparcial.

Nesse sentido, GILBERTO JABUR salienta que “(...) torna-se, pois, necessário não só defender a liberdade de imprensa, mas também a liberdade em face da imprensa." 146

Em um país em que a imprensa viveu por tantos anos sob a censura do Estado, os meios de comunicação têm dificuldade de traçar os seus limites, de saber até onde podem ir o direito de informar e a liberdade de imprensa, de forma que a notícia não fira outros direitos fundamentais igualmente protegidos pela Constituição Federal. Diz EDILSOM FARIAS que “tem sido um aprendizado duro e difícil para nós, depois de muitos anos de regime de censura, conviver numa sociedade sem censura oficial do Estado" 147

\subsubsection{Ponderação de princípios e direitos fundamentais}

ROBERT ALEXY, em obra dedicada à exegese dos direitos fundamentais, cunhou o mais conhecido e importante método de solução de conflitos entre tais direitos.

\footnotetext{
${ }^{146}$ JABUR, Gilberto Haddad. Liberdade de Pensamento e Direito à Vida Privada: conflitos entre direitos da personalidade. São Paulo: Editora Revista dos Tribunais, 2000. p. 164-165 .

${ }^{147}$ FARIAS, Edilsom Pereira de. Democracia, censura e liberdade de expressão e informação na Constituição Federal de $1988 . \quad$ Disponível em http://jus2.uol.com.br/doutrina/texto.asp?id=2195>. Acesso em 11 out. 2010.
} 
Segundo o autor alemão, os princípios e as regras são espécies do gênero norma e as regras são normas que descrevem condutas aplicáveis a um conjunto delimitado de situações. Ocorrendo a hipótese de incidência prevista na regra, essa deverá ser aplicada ao fato. Uma regra não pode aplicar-se parcialmente a um caso, ou ela é aplicada inteiramente ou será descumprida. No conflito entre regras, uma excluirá a outra, já que se uma regra não pode aplicar-se parcialmente, duas regras conflitantes não podem conviver ${ }^{148}$.

Os princípios, por sua vez, são normas que expressam valores e devem ser cumpridas na maior medida possível ou, nas palavras de ALEXY, “(...) dentro de possibilidades jurídicas e reais existentes" ${ }^{149}$. Ao contrário do que ocorre com as regras, um princípio é um mandamento de otimização, portanto, quando um princípio colide com outro, um deles cede em relação ao outro na precisa medida exigida pelas circunstâncias do caso concreto, sem que o princípio afastado deixe de existir no mundo jurídico. Assim, os princípios devem ser ponderados no caso concreto ${ }^{150}$, através do postulado da proporcionalidade, de forma tal que se aproveite o máximo de cada um deles ${ }^{151}$.

Boa parte dos direitos fundamentais são concretizações do princípio da dignidade da pessoa humana, previsto no inciso III do artigo $1^{\circ}$ da Constituição Federal. Portanto, os direitos fundamentais, de forma geral, possuem as mesmas características normativas dos princípios e, quando em choque uns com os outros, deverão ser ponderados no caso concreto.

\footnotetext{
${ }^{148}$ ALEXY, Robert. Teoria de los derechos fundamentales. Tradução: Ernesto Garzón Valdés. Madrid: Centro de Estúdios Políticos y Constitucionales, 2002. p. 92.

${ }^{149}$ Ibid. p. 90.

${ }^{150}$ Ibid. p. 91

${ }^{151}$ Ibid. p. 93
} 


\subsubsection{Critérios de ponderação}

No que tange especificamente ao confronto entre os direitos fundamentais às liberdades de expressão, imprensa, comunicação e à informação e os direitos da personalidade, a doutrina e a jurisprudência elencam alguns critérios de ponderação de direitos, a seguir descritos.

Como já debatido anteriormente, as liberdades aqui tratadas, como qualquer outro direito fundamental, não são absolutas. Entretanto, de acordo com a doutrina da posição preferencial, acatada pelo Supremo Tribunal Federal em diversos julgados, sobre os quais se falou no Capítulo I acima, nos conflitos entre as liberdades de expressão, imprensa e comunicação e o direito à informação com outros direitos fundamentais, aquelas, a princípio, em razão da sua importância para a democracia pluralista, devem prevalecer, em que pesem as posições em contrário ${ }^{152}$.

EDILSOM FARIAS elenca, em obra sobre o tema, os dois critérios sugeridos pela Suprema Corte norte-americana para definir esse confronto. São eles: a existência de interesse público, tendo em vista que não há razão para conceder posição preferencial às notícias que se referem ao âmbito privado, e a diligência do jornalista, a fim de investigar se ele teve compromisso com a verdade ${ }^{153}$.

Além desses dois critérios de ponderação, o professor LUís ROBERTO BARROSO elenca alguns outros.

O primeiro deles é a licitude no meio empregado na obtenção da informação, pelo qual se entende que, quando a fonte da notícia for ilícita, a liberdade de imprensa e o direito de informar devem ceder em relação aos direitos da personalidade. Enquadram-se aqui as notícias que relatam

\footnotetext{
${ }^{152}$ Para Edilsom Pereira de Farias, “(...) no processo de ponderação, não se atribui primazia absoluta a um ou a outro princípio ou direito". FARIAS, Edilsom Pereira de. Democracia, Censura e Liberdade de Expressão e Informação na Constituição Federal de 1988. Op. Cit.

${ }^{153}$ Ibid.
} 
informações sob segredo de justiça, cuja licitude é controvertida, como já debatido linhas acima.

O segundo critério trazido pelo professor é aquele relacionado à pessoa objeto da notícia. Segundo ele, as pessoas públicas gozam de proteção mais restrita dos seus direitos da personalidade do que aquelas que não são conhecidas. Nesse sentido já decidiu o Superior Tribunal de Justiça por diversas vezes, sempre deixando claro que a limitação dos direitos das pessoas públicas não significa que elas não os tenham, como se vê no acórdão abaixo, cujo Ministro relator foi Luis Felipe Salomão:

\footnotetext{
"Alguns aspectos da vida particular de pessoas notórias podem ser noticiados. No entanto, o limite para a informação é o da honra da pessoa. (...) Notícias que têm como objeto pessoas de notoriedade não podem refletir críticas indiscriminadas e levianas, pois existe uma esfera íntima do indivíduo, como pessoa humana, que não pode ser ultrapassada". ${ }^{154}$
}

O terceiro critério da lista é o do local de ocorrência do fato. Por esse critério, entende-se que os fatos ocorridos em locais públicos são, em princípio, noticiáveis.

O quarto critério é o da natureza do fato. Se sobre o fato narrado houver evidente interesse jornalístico, a notícia sobre ele se justifica ainda que exponha a intimidade, a honra ou a imagem de pessoas nele envolvidas. Entende o professor que os fatos criminosos são um exemplo de fatos sobre os quais há evidente interesse jornalístico. Assim, no caso das notícias sobre crimes, ainda que se entenda que essas violam o princípio da presunção de inocência e os direitos da personalidade do retratado, por esse critério, o direito à informação deverá prevalecer.

Por fim, o quinto e último critério elencado por BARROSO é o critério da existência de interesse público na divulgação dos fatos, interesse esse

\footnotetext{
${ }^{154}$ STJ. Resp 984.803. Rel. Ministra Nancy Andrighi. Brasília, 26 mai. 2009.
} 
que se presume quando os fatos estão relacionados a órgãos públicos, em razão do disposto no artigo $5^{\circ}$, inciso XXXIII, da Constituição Federal ${ }^{155}$.

\subsubsection{O papel do Poder Judiciário no conflito}

Sobre a existência do conflito entre os direitos fundamentais às liberdades de expressão, imprensa, comunicação e à informação e os direitos da personalidade não há, portanto, dúvidas. O que se discute, de acordo com LUís ROBERTO BARROSO, é “(...) a extensão do poder do Judiciário na matéria, especialmente no que diz respeito à possibilidade de impedir previamente o exercício da liberdade de expressão em deferência à intimidade e à vida de terceiros" 156 .

Assegura o professor que, em regra, as eventuais violações aos direitos fundamentais devem ser apuradas mediante o devido processo legal e resolvidas através das perdas e danos. Como foi visto no Capítulo II, busca-se com isso evitar a censura prévia aos meios de comunicação, já que, segundo parte da doutrina, essa é mais perigosa para a democracia do que o sistema de responsabilizações posteriores, tendo em vista que nele as ideias chegam ao conhecimento do público ao menos uma vez. No entanto, como se tem dito ao longo de todo este trabalho, as responsabilizações posteriores acabam por ter o mesmo efeito inibidor da censura prévia, gerando a autocensura nos meios de comunicação.

Dessa forma, ainda que bem-intencionado, qualquer tipo de censura é antidemocrático e deve ser evitado. Afinal, a censura não é uma punição apenas dos meios de comunicação, que são impedidos de manifestar-se, mas agride toda a sociedade, que é privada do acesso às informações e

\footnotetext{
${ }^{155}$ BARROSO, Luis Roberto. Colisão entre Liberdade de Expressão e Direitos da Personalidade. Critérios de Ponderação: Interpretação Constitucionalmente adequada do Código Civil e da Lei de Imprensa. Artigo disponível em <http://www.migalhas.com.br/arquivo_artigo/art_03-1001.htm>. Acesso em 15 set. 2010.

${ }^{156}$ BARROSO, Luis Roberto. Liberdade de expressão, censura e controle da programação de televisão na Constituição de 1988. In: Temas de direito constitucional, t.I. $2^{\mathrm{a}}$ ed. Rio de Janeiro: Renovar, 2001. p. $341-387$.
} 
opiniões, necessárias para que cada um possa formar livremente suas convicções e fazer suas escolhas.

Saliente-se que, no Brasil, as restrições aos meios de comunicação têm, em geral, origem no Poder Judiciário, sobretudo nas instâncias inferiores desse. O Supremo Tribunal Federal, apesar de alguns desvios, tem proferido decisões importantes na defesa das liberdades de expressão, imprensa, comunicação e do direito à informação.

Cumpre esclarecer, por fim, que o maior problema da interferência do Poder Judiciário nesse conflito é que, em geral, os direitos fundamentais são apenas argumentos usados para justificar necessidades políticas de não se ver noticiados determinados casos, como restará claro da leitura de algumas das decisões selecionadas no próximo capítulo, o que põe em xeque a democracia das decisões. 


\section{A CENSURA JUDICIAL - PRÉVIA E A POSTERIORI - À IMPRENSA NA COBERTURA DOS CASOS SUB JUDICE}

Neste Capítulo serão apresentados alguns casos e decisões judiciais que indicam como tem se posicionado a jurisprudência brasileira sobre a cobertura dos casos sub judice pela imprensa.

Como se verá, não são poucos os casos de censura judicial à imprensa, isto é, de cerceamento da expressão dos veículos de comunicação pelo Poder Judiciário, seja antes ou depois da publicação, através do pagamento de indenizações por danos morais.

Por outro lado, não é raro também que a imprensa exagere nas reações a certas decisões judiciais e que critique, muitas vezes sem razão, o Poder Judiciário.

Em suma, ver-se-á como a relação de tensão e mútua desconfiança entre o Poder Judiciário e os meios de comunicação tem levado a erros de ambas as partes, prejudicando, principalmente, a sociedade.

\subsection{A tendência do Poder Judiciário do Brasil}

Como visto nos capítulos precedentes, a censura no Brasil tem, atualmente, origem no Poder Judiciário, em especial, nas primeiras instâncias desse. Apesar de em grande parte das vezes as decisões desfavoráveis às liberdades de imprensa e expressão e ao direito à informação serem revertidas nas instâncias superiores do Poder Judiciário principalmente pelo Supremo Tribunal Federal - essas acarretam grandes prejuízos à democracia, na medida em que intimidam jornalistas a não escreverem sobre os assuntos censurados. Até porque as revisões das decisões em questão, em regra, levam anos para acontecer. 
Grande parte dos casos de censura aos meios de comunicação tem origem em comarcas do interior do Brasil e, por isso, não geram muita repercussão, uma vez que não atingem veículos de comunicação de grande importância.

De acordo com o último levantamento das decisões judiciais a respeito do tema aqui tratado, realizado em 2004 pelo Ministro do Superior Tribunal de Justiça EDSON CARVALHO VIDGAL, até outubro de 2003, havia 3.342 ações tramitando na Justiça apenas contra os cinco maiores grupos de comunicação do Brasil, figurando nessa lista as Organizações Globo emissora de rádio, TV, jornais e revistas - a Editora Abril, a Editora Três, os jornais, "O Estado de S. Paulo" e "Folha de São Paulo" 157.

\subsection{A motivação das decisões judiciais}

Não obstante as garantias conferidas pela Constituição Federal às liberdades de expressão, imprensa, comunicação e ao direito à informação, essas têm sido constantemente violadas pelo Poder Judiciário sob a alegação de proteção dos direitos da personalidade e de preservação da imparcialidade do Juiz.

Entende a Associação Nacional de Jornais (ANJ) que as decisões judiciais que violam as referidas liberdades são, em verdade, motivadas por ações de governantes e ex-governantes inconformados com a livre divulgação de informações ao seu respeito ${ }^{158}$.

Também o Ministro AYRES BRITTO, do Supremo Tribunal Federal, parece entender da mesma forma. Declarou ele, quando do julgamento da ADPF $\mathrm{n}^{\circ} 130$, que a liberdade constitucional de relatar e opinar deve

\footnotetext{
${ }^{157}$ VIDGAL, Edson Carvalho. Censura da Imprensa pelo Poder Judiciário. Disponível em < http://bdjur.stj.gov.br/xmlui/bitstream/handle/2011/255/Censura_da_Imprensa.pdf?sequence=1 > . Acesso em 15 out. 2010. p. 05.

${ }^{158}$ Associação Nacional de Jornais. Relatório sobre liberdade de imprensa no Brasil. Disponível em <http://www.anj.org.br/programas-e-acoes/relatorios/relatorios-de-liberdade-deimprensa/copy_of_rellibim2004_2006.pdf >. Acesso em 10 out. 2010. p. 11.
} 
prevalecer apesar do "reprovável modismo da 'censura judicial' operada sob as vestes da proteção aos direitos da personalidade" ${ }^{159}$.

\subsection{Os casos sub judice e as decisões judiciais contra a imprensa}

Embora haja inúmeras decisões judiciais que implicam no cerceamento da expressão dos veículos de comunicação e variados argumentos nelas utilizados, aqui serão apresentados apenas os casos em que o Poder Judiciário se valeu da censura para evitar a influência da mídia nas investigações policiais e nos processos judiciais, bem como na preservação do segredo de justiça, de forma a garantir a imparcialidade dos julgadores e a integridade dos direitos da personalidade.

\subsubsection{Censura judicial prévia}

Têm se tornado cada vez mais numerosos os casos de censura prévia através de decisões liminares, que, muitas vezes, são reformadas pelo mesmo órgão jurisdicional quando da decisão definitiva, o que pode indicar o pouco cuidado dedicado a tais decisões. A seguir, veremos alguns deles.

\subsubsection{Renato Mehanna Khamis versus Editora Abril S/A, UOL Universo Online Ltda., AOL Brasil Ltda., Rádio e Televisão Bandeirantes Ltda. e Valor Econômico S/A.}

Por decisão da Juíza MARIA DORALICE NOVAES, do Tribunal Regional do Trabalho da $2^{\mathrm{a}}$ Região, os grupos de comunicação Editora Abril S/A, UOL Universo Online Ltda., AOL Brasil Ltda., Rádio e Televisão Bandeirantes Ltda. e Valor Econômico S/A ficaram proibidos de veicular qualquer notícia sobre o procedimento administrativo instaurado no Tribunal Regional do Trabalho de São Paulo, para apurar denúncias contra o Juiz Renato Mahanna Khamis. As denúncias foram formuladas por

${ }^{159}$ STF, ADPF 130, Rel. Ministro Carlos Britto. Brasília, 30 abr. 2009. Op Cit. p. 07. 
servidoras públicas lotadas no gabinete do Juiz, acerca de suposta prática de atos que, em tese, configurariam crime de assédio sexual.

Durante mais de um ano o procedimento correu sob segredo de justiça, em virtude da referida decisão judicial, que acatou as alegações do Juiz investigado, no sentido de que as notícias acabariam por "afetar sua honra e bom nome, bem como a credibilidade do Poder Judiciário". ${ }^{160}$

Por decisão do Juiz CARlos RoBerto Petroni, da $4^{\text {a }}$ Vara Cível de Pinheiros, no entanto, os veículos de comunicação prejudicados pela decisão anterior passaram a poder noticiar o caso, corroborando a ideia expressa no Capítulo III acima de que o segredo de justiça é o segredo sobre as questões internas do processo, não podendo impedir a narrativa dos fatos pela imprensa. Nesse sentido diz o juiz:

“(...) o artigo 27 da Lei Orgânica da Magistratura Nacional prevê que a instauração de procedimentos administrativos visando à destituição de magistrados (parágrafo $2^{\circ}$ ), bem como o seu julgamento (parágrafo $6^{\circ}$ ), sejam realizados em sessão secreta. (...) Contudo, quer as disposições contidas em tais dispositivos, quer o deferimento do processamento do feito administrativo sob a égide do segredo de justiça pela I. Juíza Maria Doralice Novaes, não têm o condão de obstar a publicação de qualquer notícia "relacionada direta ou indiretamente" com os fatos narrados em ambas as petições iniciais. Ocorre que o "segredo de justiça" invocado pelo requerente, abrange tão somente os atos processuais tais quais os depoimentos, autos, audiências, decisões e provas produzidas no processo, não alcançando o fato em si, (...)"161

Vai, ainda, além o Juiz ao dizer:

"Assim, (...) ampliar o alcance do segredo de justiça, de modo a que ele abarque a proibição da divulgação de fatos de notório interesse público, quais aqueles acerca do qual versa a demanda, no meu entender, constitui ilegalidade e inconstitucionalidade." ${ }^{162}$

Por fim, conclui o magistrado que a proibição dos veículos de comunicação de noticiar o caso constitui verdadeira censura prévia, o que é proibido pela Constituição Federal. Segundo ele, as violações à intimidade,

\footnotetext{
160 4 Vara Cível de Pinheiros, Processo no 011.02.001.112-2 e 011.01.021.146-3, Juiz Carlos Roberto Petroni. São Paulo, 14 ago. 2003.

${ }^{161}$ Ibid. (grifei)

${ }^{162}$ Ibid. (grifei)
} 
vida privada, à honra e à imagem das pessoas devem ser reparadas por meio da reparação posterior pelo dano material ou moral decorrente da manifestação da imprensa.

\subsubsection{O caso do governador Carlos Gaguim}

Em 24 de setembro de 2010, o corregedor-geral do Tribunal Regional Eleitoral do Tocantins, desembargador LIBERATO PÓVOA, proibiu, em caráter liminar, oitenta e quatro veículos de comunicação de publicarem notícias que relacionassem o governador Carlos Gaguim, do PMDB, candidato à reeleição, às conversas telefônicas interceptadas pela Polícia Federal em uma investigação protegida pelo segredo de justiça.

Entendeu o desembargador que os meios de comunicação são destinatários do sigilo de justiça e, portanto, estaria presente "o fummus boni iures, por contrariar a legislação que resguarda o sigilo das investigações, garante a presunção de inocência e enaltece a dignidade humana" 163. Alegou, ainda, o desembargador que "o que se veicula maliciosamente na mídia, é fruto de informação obtida por meio ilícito.” 164

Com isso, deferiu o pedido liminar, determinando que os meios de comunicação listados em sua decisão se abstivessem da utilização - "de forma direta ou indireta" ${ }^{165}$ - ou da publicação dos dados relativos ao candidato Carlos Gaguim. Vê-se que, além de estender o alcance do segredo de justiça aos fatos para além dos procedimentos investigatórios, a decisão traz ainda uma incerteza indesejável, tendo em vista que não é clara no seu alcance, já que qualquer referência ao governador poderia ser entendida como menção "indireta" ao mesmo.

\footnotetext{
163 TRE/TO, Representação ${ }^{\circ}$ 1.594-44.2010.6.27.0000, Rel. Desembargador Liberato Povoa. Palmas, 24 set. 2010.

${ }_{164}$ TRE/TO, Representação $n^{\circ}$ 1.594-44.2010.6.27.0000, Rel. Desembargador Liberato Povoa. Palmas, 24 set. 2010.

${ }^{165}$ Ibid.
} 
Por envolver um candidato à reeleição e em razão da proximidade com as eleições, o caso teve grande destaque na imprensa, de modo que o próprio Gaguim pediu a suspensão da liminar e, apenas três dias depois da concessão dessa, o plenário do TRE de Tocantins suspendeu os efeitos da medida.

\title{
4.3.1.3 Um caso paradigmático: censura ao "Estadão"
}

Em 24 de julho de 2009, o empresário Fernando José Macieira Sarney propôs uma ação inibitória com pedido liminar, na $12^{\mathrm{a}}$ Vara Cível do Distrito Federal, a fim de impedir que o Jornal "O Estado de S. Paulo" publicasse matérias jornalísticas a respeito de dados protegidos pelo segredo de justiça e obtidos em procedimento de investigação criminal do inquérito relativo à "Operação Boi Barrica" 166, da Polícia Federal, que envolvia, dentre outros, o filho de José Sarney.

O Juiz DANIEL FeliPe MACHADO, da $12^{\mathrm{a}}$ Vara Cível do DF, não concedeu a liminar, sob a seguinte alegação:

\begin{abstract}
“(...) impedir de plano a circulação ou divulgação de matéria jornalística avulta-se como um sacrifício do direito constitucional de informação e liberdade de imprensa que nem mesmo a lei poderá, ao amparo da constituição vigente, $\S 1^{\circ}$, do artigo 220, constituir. (...) a divulgação das conversas telefônicas que o requerente pretende se acautelar tornou-se um fato notório amplamente divulgado por toda a imprensa adquirindo a configuração de um fato público, para o qual não se justifica a intromissão judicial para conter a exposição da mídia ou até do próprio conteúdo da informação sob o argumento da tutela do direito da personalidade." 167
\end{abstract}

Em 30 de julho de 2009, no entanto, o desembargador DÁCIO VIEIRA, da $5^{\text {a }}$ Turma Cível do Tribunal de Justiça do Distrito Federal, proibiu, em sede de Agravo de Instrumento, em decisão liminar, o jornal “ $\mathrm{O}$ Estado de S. Paulo" de publicar qualquer informação relativa à "Operação Boi Barrica". Caso o jornal descumprisse a referida decisão, seria punido

\footnotetext{
${ }^{166}$ Trata-se do procedimento de investigação criminal do inquérito 2007.37.00.0001752-4.

${ }^{167} 12^{\mathrm{a}}$ Vara Cível do Distrito Federal, Ação Inibitória com pedido liminar n ${ }^{\circ}$ 2009011113988-3, Juiz Daniel Felipe Machado. Brasília, 27 jul. 2009.
} 
com multa no valor de $\mathrm{R} \$ 150$ mil por reportagem publicada. Alega o desembargador que o que está em exame é a divulgação dos dados sob sigilo e não dos fatos investigados. Nas suas palavras:

“(...) o que se traz a exame nesta instância jurisdicional, como visto, é a conduta de particulares, empresa jornalística, consistente na obtenção e ampla divulgação de dados obtidos por interceptação judicial de comunicações telefônicas, velados pelo segredo de justiça, em atividade privada de imprensa, desprovida de qualquer oficialidade investigatória, em detrimento de pessoa submetida à medida cautelar de quebra de sigilo telefônico.” 168

Ressalta o julgador que a jurisprudência, inclusive do STF, tem se posicionado no sentido de preservar o sigilo. Destaca ele:

"Importa ressaltar, por oportuno, a grande preocupação na quadra judicial, nos diversos órgãos que compõem o Judiciário Nacional, quanto ao estabelecimento de severas medidas atinentes à preservação do sigilo legal imposto a essa espécie de dados extraídos da vida privada no interesse da investigação criminal, a exemplo do que dispõem as recentes Resoluções editadas pelo Conselho Nacional de Justiça-CNJ, no 59, de 09 de setembro de 2008 e 84, de 06 de julho de 2009, além de constituir crime a conduta prevista no art. 10, da Lei $n^{\circ}$ 9296/96, consistente em "quebrar segredo da Justiça, sem autorização judicial ou com objetivos não autorizados em lei" 169

Em 22 de setembro, "O Estado de S. Paulo" recorreu da decisão e o pleno do Tribunal de Justiça do Distrito Federal, em 30 de setembro, declinou da competência para a Justiça Federal do Maranhão, além de manter a decisão do desembargador DÁcIO VIEIRA.

Alegava o jornal, na tentativa de sustar a liminar concedida por DÁCIO VIEIRA, a suspeição do julgador, tendo em vista a ligação do desembargador com a família Sarney. Apesar de DÁcIO VIEIRA ter sido afastado da relatoria do caso, a liminar, como dito, não foi sustada.

Em seguida, o jornal impetrou mandado de segurança ${ }^{170}$, contra ato do desembargador DÁCIO VIEIRA, em sua decisão monocrática em sede do

\footnotetext{
${ }_{168}$ TJ/DF, Agravo de Instrumento $\mathrm{n}^{\circ}$ 2009002010738-6, Rel. Desembargador Dácio Vieira. Brasília, 31 jul. 2009.

${ }^{169}$ Ibid.

170 TJ/DF, Mandado de Segurança $n^{\circ}$ 200900211261-7, Rel. Desembargador Waldir Leôncio Junior. Brasília, 13 ago. 2009.
} 
Agravo de Instrumento acima citado. Em 13 de agosto de 2009, o desembargador WALDIR LEÔNCIO JUNIOR não acolheu o pedido de liminar do mandado de segurança em questão.

Em novembro de 2009, o "Estadão" ingressou com uma Reclamação Constitucional, com pedido liminar, no Supremo Tribunal Federal, alegando que a decisão do TJ/DF violava a decisão daquela Corte em sede da ADPF $\mathrm{n}^{\circ}$ 130, já mencionada acima, que revogou a Lei de Imprensa (Lei 5.250 de 1967). O Ministro CÉSAR PELuso, relator da Reclamação, afirmou, em seu voto, não haver qualquer contrariedade à decisão em sede da ADPF $n^{\circ} 130$, tendo em vista que não houve aplicação da Lei de Imprensa ao caso e que a decisão da ADPF em nenhum momento afirmou a absoluta impossibilidade de proteção dos direitos da personalidade em face da liberdade de imprensa. Entendeu o relator, de maneira acertada, que a "reclamante recorreu à via imprópria para lográ-lo, o que, à evidência, não o impede de valer-se dos remédios jurídico-processuais adequados para tanto" ${ }^{171}$. Com essa fundamentação, a Reclamação foi extinta sem resolução do mérito.

Em 18 de dezembro de 2009, Fernando Sarney desistiu da ação, o que não foi aceito pela parte ré.

Atualmente, portanto, o caso tramita na Justiça Federal do Maranhão.

A censura ao jornal "O Estado de S. Paulo" gerou reações em diversos países. Essa não é, no entanto, uma reação-padrão em casos de censura desse tipo ${ }^{172}$ e só aconteceu em função da importância do veículo censurado e, talvez, do motivo político da censura. Afinal, de acordo com muitos jornalistas, caso as informações pudessem ter vindo a público, poderiam ter ajudado a mobilizar a opinião pública em favor da renúncia ou

\footnotetext{
${ }^{171}$ STF, Reclamação 9428/DF, Rel. Ministro Cezar Peluso. Brasília, 10 dez. 2009.

${ }^{172}$ SILVA, Carlos Eduardo Lins. Op. Cit. p. 14.
} 
destituição de José Sarney do cargo de Presidente do Senado Federal, em virtude das denúncias de corrupção e nepotismo existentes contra ele.

Nesse caso ficou claro o efeito inibidor gerado pela censura judicial, tendo em vista que, embora a decisão do TJ/DF não tenha mencionado nenhum outro veículo de comunicação, após a censura ao "Estadão", nenhum outro jornal, por mais de dois meses, publicou qualquer notícia sobre o caso da "Operação Boi Barrica".

Apesar de a imprensa ter condenado a decisão do STF, alegando que a Corte teria mantido a censura ao "Estadão", a decisão foi correta e simplesmente não entrou no mérito da censura porque não se tratava da ação cabível para tanto e o Poder Judiciário só pode agir quando provocado, conforme determina o artigo $2^{\circ}$ do Código de Processo Civil.

Ademais, aparentemente a imprensa não entendeu a decisão proferida pelo desembargador DÁCIO VIEIRA, já que são inúmeras as críticas ao fato de tal decisão ter proibido qualquer manifestação sobre a família Sarney, o que em nenhum momento ocorreu, como se percebe pela explicação dada pelo desembargador:

\footnotetext{
"Mas todo esse contexto veio a ser totalmente desvirtuado pelo Jornal O Estado de São Paulo que, mesmo com amplo conhecimento do processo e dos lindes da decisão, passou a divulgar sua matéria com o matiz de uma inventiva "censura prévia", buscando levar a opinião pública ao equivocado entendimento de que o jornal estava impedido de publicar qualquer matéria ou informação sobre o andamento das investigações que envolvam o nome do agravante, Fernando Macieira Sarney, o que, como antes visto, jamais ocorreu, permanecendo intocável, inviolável, pelos limites da decisão, o mais amplo direito da lícita expressão, pensamento, opinião e informação acerca do caso, procedimento este posto "a latere" dos seus leitores, pelo próprio cunho sensacionalista alcançado a este viso, por esse renomado e tradicional veículo de imprensa, a revelar uma conduta delineada, temerária e porque não lamentável, sob o ponto de vista da ética jornalística, de princípios deontológicos. ${ }^{173}$
}

\footnotetext{
${ }^{173}$ TJ/DF, Ofício GPR no 009/GD/2009 em Mandado de Segurança n ${ }^{\circ}$ 200900211261-7, Rel. Ministro Waldir Leôncio Junior. Brasília, 18 ago. 2009. (grifei)
} 
Houve, como se vê, um exagero por parte da imprensa, que, ao não publicar nada a respeito da família Sarney estava, em verdade, se autocensurando, como bem asseverou DALMO DE ABREU DALLARI:

"Só ficou proibida a publicação dos dados obtidos durante a investigação sigilosa. Nada impede a publicação da decisão judicial, como também a publicidade de todos os dados que forem obtidos sobre a pessoa e os negócios de Fernando Sarney, desde que obtidos por qualquer outro meio que não a investigação criminal sigilosa." 174

Assim, ainda que seja questionável a decisão sobre o segredo de justiça, na medida em que se discute, como amplamente debatido no Capítulo III, se os jornalistas devem ou não respeitar o sigilo imposto, em princípio, aos funcionários públicos, é evidente que há um exagero por parte da imprensa e do próprio jornal atingido pela decisão.

Por outro lado, a decisão do desembargador DÁcIO VIEIRA e as repercussões sobre ela na imprensa trazem à tona outro interessante debate sobre as relações entre o Poder Judiciário e a imprensa. Se, de um lado, a imprensa condena, muitas vezes injustamente, o Poder Judiciário, ora pela sua morosidade ou suposta manutenção da impunidade, ora por suas decisões contra a imprensa e a liberdade de expressão, de outro lado o Poder Judiciário se utiliza de linguagem rebuscada e, quase sempre, incompreensível pela imprensa e pela população em geral $^{175}$.

\subsubsection{Rede Globo de Televisão, TV Clube e jornalista Roberto Cabrini versus Desembargador Albuquerque e família}

Em 2001, o desembargador José Albuquerque, sua filha, Ingrid Albuquerque, e seu genro, João Ulisses Azevedo, propuseram ação de

\footnotetext{
${ }^{174}$ DALLARI, Dalmo de Abreu. Estadão, censura $e$ autocensura. Disponível em <http://www.observatoriodaimprensa.com.br/artigos.asp?cod=559JDB007>. Acesso em 15 out. 2010 .

${ }^{175}$ Com o objetivo de evitar que isso ocorra, foi proposto o Projeto de Lei $n .^{0} 7.448 / 06$, que visa a alterar o Código de Processo Civil, para determinar que os juízes redijam com linguagem simples o dispositivo - a parte em que o magistrado conclui a sentença e efetivamente decide, depois de apresentar um relatório do caso e os fundamentos que o levaram à conclusão.
} 
reparação por danos morais, com pedido de liminar, em desfavor da Rede Globo de Televisão, da TV Clube, sua afiliada, e do jornalista Roberto Cabrini, no valor de $\mathrm{R} \$ 2,5$ milhões, pelos supostos danos que lhes teriam causado as reportagens sobre o crime organizado, tráfico de influência e cobrança de propinas por integrantes do Tribunal de Justiça do estado de Piauí, realizadas pelos réus.

Em $1^{\circ}$ de fevereiro de 2001, o Juiz ANTôNio PerEs PARENTE, da $3^{\mathrm{a}}$ Vara Cível de Teresina, no Piauí, proibiu, em decisão liminar, a Rede Globo de Televisão, a TV Clube e o jornalista Roberto Cabrini de citar, de qualquer forma, os nomes do desembargador José Albuquerque, da filha e do genro dele, sob pena de multa diária no valor de $\mathrm{R} \$ 5 \mathrm{mil}^{176}$.

Em $1^{\circ}$ de dezembro de 2009, a $3^{\text {a }}$ Câmara Cível do Tribunal de Justiça do Piauí, em decisão cujo relator foi o desembargador FRANCISCO LANDIM, derrubou, oito anos depois, a liminar que impedia a Rede Globo de Televisão, a TV Clube e o jornalista Roberto Cabrini, de citarem os nomes do desembargador José S. Albuquerque e de sua família.

A demora na suspensão da liminar se deve, em grande parte, ao fato de que, ao longo dos oito anos, dezesseis desembargadores se julgaram suspeitos ou impedidos para decidir.

O desembargador relator se valeu em sua decisão, dentre outros argumentos, do critério de ponderação, de que tratou o Capítulo III, pelo qual o direito à intimidade, à vida privada e à imagem das pessoas públicas é mitigado. Diz ele:

“(...) no caso em apreço não verifico invasão na vida privada dos Agravados, mas sim à divulgação de denúncias relativas à atividade jurisdicional, exercida, neste Tribunal, pelo então Desembargador - Des. José Soares de Albuquerque, atualmente aposentado-, na condição de homem público, e à influência que os outros Agravados teriam nessas atividades, em decorrência da relação de

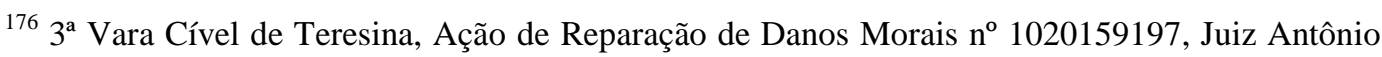
Peres Parente. Teresina, $1^{\circ}$ fev. 2001.
} 
parentesco existente entre estes e o já citado desembargador, quais sejam, a de filha (Ingrid Soares de Albuquerque) e genro (João Ulisses de Brito Azedo)." 177

Lembra, ainda, o julgador que a divulgação de fatos como esse, de corrupção, é um dever da imprensa, no exercício de sua função de informar. Expõe o desembargador:

\begin{abstract}
“Ademais, observa-se que a Agravante não apenas exerceu de forma responsável as liberdades constitucionalmente outorgadas, como cumpriu a tarefa que por meio de concessão, lhe foi outorgada pelo Estado, a saber, a divulgação de fatos públicos relevantes, possibilitando o fomento à transparência no exercício do poder." 178
\end{abstract}

Por fim, constata o desembargador que a simples reprodução de informações constantes de denúncia do Ministério Público não configura lesão à moral dos retratados. Nas palavras dele:

“(...) não se configura lesão à moral a simples reprodução de informações constantes em denúncia oferecida pelo Ministério Público, numa atividade configurada de animus narrandi, que não ultrapassa os limites da narrativa." 179

$\mathrm{O}$ caso em tela demonstra que, ainda que sejam benéficas as reformas das decisões que censuram a imprensa, essas, de forma geral, levam anos para acontecer, o que faz com que, durante todo o tempo transcorrido entre a censura e o fim dessa, o veículo diretamente censurado, e também outros que acabam por autocensurar-se, deixem de tratar do caso.

\title{
4.3.1.5 Tribuna Popular versus Dari Pagel
}

No dia 21 de julho de 2001, a Juíza substituta ANA PAULA BRAGA Alencastro, da Comarca de São Lourenço do Sul, no estado do Rio Grande do Sul, concedeu medida liminar na ação de busca e apreensão,

\footnotetext{
${ }^{177}$ TJ/PI, $3^{\text {a }}$ Câmara Cível, Agravo de Instrumento nº 01.000195-6, Rel. Desembargador Francisco Landim. Teresina, $1^{\circ}$ dez. 2009. (grifei)

${ }^{178}$ Ibid. (grifei)

${ }^{179}$ Ibid.
} 
movida pelo Prefeito de São Lourenço, Dari Pagel, determinando a apreensão da edição quinzenal do jornal “Tribunal Popular", que trazia reportagem sobre a denúncia, do Ministério Público, de improbidade administrativa contra o prefeito.

Em 12 de agosto de 2003, portanto mais de dois anos depois da concessão da liminar, o Juiz DIEGo LEONARDo Di MARCo PIÑEIRO, titular da Comarca de São Lourenço, revogou a liminar e julgou improcedente a ação.

Em resposta à alegação do autor de que o jornal teria indevidamente o chamado de 'réu', de forma a “(...) compará-lo junto à opinião pública como praticante de um ato criminoso (...)" ${ }^{180}$, aduz o Juiz na sentença que “(...) o termo 'réu' é apropriado para designar pessoa que responde ação civil pública por atos de improbidade administrativa." 181

Diz, ainda, o Juiz que, apesar de o caso estar sub judice e não haver nada provado contra o prefeito, o jornal não realizou prejulgamentos, mas apenas narrou os fatos. Assim:

“(...) não houve impropriedade ou inverdade na manchete veiculada no Jornal Tribuna Popular. (...) as pequenas incorreções que constaram do corpo da matéria, que são normais nos meios de comunicação, não são suficientes para justificar a excepcional restrição à liberdade de imprensa." ${ }^{182}$

\subsubsection{Cesura judicial a posteriori}

Mais numerosos ainda que os casos de censura prévia são os casos de condenações de jornalistas e veículos de comunicação ao pagamento de indenizações por danos morais, muitas das vezes altíssimas, que, como demonstrado no Capítulo II acima, acabam por ter o mesmo efeito inibidor da expressão que a censura prévia.

\footnotetext{
${ }^{180}$ Comarca de São Lourenço do Sul, Processo no 067/1.03.0001565-2, Juiz Diego Leonardo Di Marco Piñeiro. São Lourenço do Sul, 12 ago. 2003.

${ }^{181}$ Ibid.

182 Ibid. (grifei)
} 


\title{
4.3.2.1 Jornal "Lance!" versus Wagner Tardelli de Azevedo
}

O Juiz AlessandRo DE OliveIRA FeliX, da 51 ${ }^{\mathrm{a}}$ Vara Cível do Rio de Janeiro, condenou, em agosto de 2010, o jornal Lance! a pagar o valor de $\mathrm{R} \$ 15$ mil, a título de indenização por danos morais, ao árbitro de futebol Wagner Tardelli de Azevedo, sob a alegação de que o periódico teria extrapolado os limites constitucionais do direito de informação.

O jornal publicou reportagem sobre suspeita de suborno e manipulação de resultado nos jogos do Campeonato Brasileiro de 2008, o que levou a Confederação Brasileira de Futebol, por cautela, a substituí-lo na partida final, disputada entre Goiás e São Paulo.

Wagner Tardelli de Azevedo ajuizou ação contra o jornal buscando o ressarcimento pelos danos morais que supostamente a reportagem lhe causara.

Interessante notar que o próprio Juiz reconhece na decisão o interesse em evitar, com condenações desse tipo, notícias semelhantes, ou melhor, o interesse em provocar a autocensura. Diz o Juiz:

\begin{abstract}
"A ocorrência de dano moral há de ser considerado não só sob um aspecto meramente ressarcitório, mas também sob o ângulo preventivo-pedagógico, visando chamar a atenção para que os fatos lesivos não tornem a ocorrer. De fato, a decisão de um processo possui um efeito endoprocessual, ou seja, perante as próprias partes, mas também há de ser ressaltado o seu efeito macroprocessual, ou seja, aquilo que extrapola os limites subjetivos da coisa julgada para expressar um comportamento esperado por toda a sociedade." 183
\end{abstract}

Interessante notar também que o Juiz ALESSANDRO DE OLIVEIRA FELIX destaca o cuidado que a imprensa deve ter para não prejulgar os acusados e não cometer injustiças, tendo em vista o importante papel que a imprensa possui como órgão formador da consciência do povo. Nas palavras do Juiz:

\footnotetext{
${ }^{183} 51^{\text {a }}$ Vara Cível do Rio de Janeiro, Processo 0089353-97.2010.8.19.0001, Juiz Alessandro Oliveira Felix. Rio de Janeiro, 09 ago. 2010. (grifei)
} 
"É pertinente acrescentar que as informações e notícias, veiculadas pelos meios sociais de comunicação, devem ser analisadas mediante uma préinvestigação própria, onde levará em consideração a ética, para que não se cometam injustiças e ofensas por fatos distorcidos ou pela não pertinência da sua publicação"184

\subsubsection{Jornal "Tapera” versus Valério Francisco de Moraes}

O jornal "Tapera" da cidade de Salto, localizada no interior do Estado de São Paulo, foi condenado a pagar indenização por danos morais no valor de R\$ 100 mil a Valério Francisco de Moraes por ter publicado notícia com base no Boletim de Ocorrência da Polícia Civil.

De acordo com a notícia, publicada no dia 22 de janeiro de 2000, o autor teria sido indiciado por entrar na cadeia, para cumprir prisão em regime semiaberto, com uma porção de maconha. $\mathrm{O}$ caso virou processo, no qual Valério Francisco de Moraes fora absolvido. O autor alega na inicial que a reportagem era “(...) irresponsável e sensacionalista” e que se tratava de investigação realizada sob segredo de justiça.

Os advogados do jornal recorreram da sentença alegando que a obrigação do sigilo nos casos de segredo de justiça é dos funcionários do Estado e não do jornal. Alegam, ainda, que a reportagem é cópia fiel do Boletim de Ocorrência, não tendo o jornal apresentado qualquer comentário adicional.

A $8^{\text {a }}$ Câmara Cível do Tribunal de Justiça de São Paulo reformou a sentença, acatando as alegações da ré, embora tenha entendido não haver na decisão de $1^{\circ}$ grau qualquer ameaça à liberdade de imprensa, como se pretendeu "exageradamente", de acordo com o acórdão, provar na apelação.

Aduz o relator do recurso, desembargador ANDRÉ AUGUSTO SALVADOR BEZERRA, que:

${ }^{184}$ Ibid. (grifei) 
"em nenhum momento, a matéria em questão expressamente realizou qualquer prejulgamento em relação ao apelado. Pelo contrário, o que existiu foi a notícia, de inegável interesse público, no sentido de que o recorrido veio a ser preso e indiciado por tráfico de entorpecente, em absoluta conformidade ao relatado por agentes da polícia civil de Salto, tendo sido, inclusive, noticiada a versão apresentada pelo apelado no momento de sua custódia. Não há, portanto, falsa acusação por parte do periódico, mas apenas o relato de um fato envolvendo o recorrido."

Acatando a tese de que os destinatários do segredo de justiça são os funcionários públicos e não os jornalistas, o desembargador assevera:

"É certo, por fim, que o artigo 26 da Lei 6.368/76 prevê o segredo de justiça até o recebimento da denúncia em casos de tráfico de entorpecente. Todavia, tal sigilo é dever imposto, tão somente, aos agentes públicos envolvidos na persecução penal, não atingindo ao cidadão comum, inclusive os jornalistas." 186

Como se vê, trata-se do debate exposto no Capítulo III, sobre se os jornalistas e veículos de comunicação seriam ou não destinatários do segredo de justiça.

\subsubsection{Jornal "O Povo" versus Maria Nilda Santos Silva e Outros}

O Jornal "O Povo", de Fortaleza, no Ceará, foi condenado ao ressarcimento dos danos morais causados às pessoas retratadas em notícia por ele publicada em 06 de dezembro de 2009. De acordo com a notícia publicada no jornal, Maria Nilda Santos Silva e outros fariam parte de uma quadrilha de traficantes de drogas. A decisão foi posteriormente confirmada pelo Tribunal de Justiça do Ceará.

Em seu voto, a desembargadora relatora, EDITE BRINGEL OLINDA ALENCAR, traz à tona o conflito narrado no Capítulo III acima, entre o dever de denunciar e o dever de veracidade dos jornalistas. Como dito linhas acima, muitas vezes, os dois deveres entram em choque. Nesse sentido, aduz a desembargadora:

\footnotetext{
${ }^{185}$ TJ/SP, Apelação Cível com Revisão no 226.995-4/2-00, Rel. Desembargador André Augusto Salvador Bezerra. São Paulo, 19 out. 2005.

${ }^{186}$ Ibid. (grifei)
} 
“(...) a Empresa Jornalística O Povo S/A, conduziu-se de forma precipitada quando da publicação da matéria que ensejou a propositura da demanda. (...) Com efeito, o Jornal $\mathrm{O}$ Povo publicou matéria jornalística, afirmando serem os apelados traficantes, membros de quadrilha denominada "Gangue do Barracal", envolvida na "Chacina do Pantanal". ${ }^{187}$

O próprio jornal posteriormente publicou notícia desmentindo os fatos, o que comprova a pouca dedicação dada à investigação dos fatos.

Lembra a desembargadora, ainda, que a rapidez necessária ao jornalismo investigativo, em busca do "furo" de reportagem algumas vezes prejudica direitos de terceiros. Diz ela:

"O fato de lançar informação com rapidez, de tudo o que se passa no mundo, não elimina a responsabilidade relativamente a notícias precipitadas, que ofendam a dignidade da pessoa humana. (...) [a ré] não buscou apurar devidamente a verdade dos fatos, compromisso de que a mídia jornalística não pode se esquivar." 188

\subsubsection{Fundação Universo versus Verônica Coutinho de Carvalho}

A Fundação Universo foi condenada, pela $6^{\mathrm{a}}$ Vara Cível de São Gonçalo, ao pagamento de indenização por danos morais no valor de R \$10 mil à Verônica Coutinho de Carvalho. A ação indenizatória foi proposta em razão da divulgação de matéria jornalística em que a autora foi acusada pela atual esposa de seu ex-namorado de ter praticado ameaças, tanto contra ela, quanto em face da filha do casal.

Posteriormente, a sentença foi reformada pela $7^{a}$ Câmara Cível do Tribunal de Justiça do Rio de Janeiro. Entendeu o TJ/RJ que a reportagem não surgiu da imaginação do jornalista que a redigiu, tendo o periódico se limitado a reproduzir o registro de ocorrência efetuado na Delegacia de Mulheres de São Gonçalo.

Destaca a desembargadora relatora, MARIA REGINA NOVA, que o fato de a retratada ter sido posteriormente absolvida não gera o dever de

\footnotetext{
${ }^{187}$ TJ/CE, $3^{\text {a }}$ Câmara Cível, Apelação Cível no 55590236200080600011 , Rel. Desembargadora Edite Bringel Olinda Alencar. Fortaleza, 04 ago. 2007. (grifei)

${ }^{188}$ Ibid.
} 
indenizar, desde que não tenha havido comprovada negligência ou má-fé por parte do informador. Aduz a desembargadora:

\begin{abstract}
"De fato, houve um registro de ocorrência no qual gerou um processo criminal de ameaça e a circunstância de, posteriormente, a autora ter sido absolvida, não torna abusiva a veiculação da matéria pela imprensa. (...) Nesse sentido, a publicação da matéria jornalística não teve o condão de ofender a honra da autora, tendo apenas o réu exercido o seu regular direito de narrar um acontecimento de que tomo conhecimento" 189
\end{abstract}

\title{
4.3.2.5 Jornal "O Dia” versus Anderson dos Santos Sermud
}

Em 2004, o Jornal "O Dia" publicou notícia relatando que o agente penitenciário Anderson dos Santos Sermud foi preso por funcionários da Coordenadoria de Inteligência do Sistema Penitenciário (Cispen), em conjunto com a direção do presídio Ary Franco, no Rio de Janeiro, quando tentava entrar na unidade com uma pistola 380 e dois carregadores.

Anderson Sermud sentiu-se prejudicado pela notícia publicada e ingressou com ação de ressarcimentos pelos danos morais supostamente lhe causados pelo jornal.

A $22^{a}$ Vara Cível da Capital do Rio de Janeiro julgou improcedente o pedido do autor, por entender a Juíza TÂNIA PAIM CALDAS DE ABREU, que o jornal somente noticiou fato que envolvia o autor, sem mencionar qualquer condenação ou conclusão, não havendo, portanto, qualquer ilícito em noticiar fato efetivamente ocorrido ${ }^{190}$.

Posteriormente, a $19^{\mathrm{a}}$ Câmara Cível do Tribunal de Justiça do Rio de Janeiro reformou a sentença, por entender que é lícito às empresas jornalísticas noticiar informações sobre as investigações de um crime, já que se trata de matéria de interesse público. No entanto, aduz o relator, desembargador MARCOS ALCINO DE AZEVEDO TORRES:

\footnotetext{
189 TJ/RJ, Apelação Cível no 0052955-84.2006.8.19.0004, Rel. Desembargadora Maria Regina Nova. Rio de Janeiro, 18 ago. 2010. (grifei)

${ }^{190} 22^{\mathrm{a}}$ Vara Cível do Rio de Janeiro, Processo n ${ }^{0}$ 0101856-58.2007.8.19.0001, Juíza Tânia Paim Caldas de Abreu. Rio de Janeiro, 02 set. 2009.
} 
“(...) tais empresas não estão autorizadas a noticiar quaisquer fatos de forma imprecisa e irresponsável, elaborando reportagens sensacionalistas que, não correspondendo à realidade ou antecipando conclusões por ela mesma elaboradas, acabam por ofender a honra daqueles que são mencionados em suas notícias" 191

Entendeu o relator que a manchete utilizada pelo jornal ("Guarda ia dar arma a presos"), no mínimo, "antecipou conclusões por sua conta de modo irresponsável eis que ainda vinha sendo apurado o fato nas esferas administrativa e criminal, vindo o autor, ao final de ambas, a ser inocentado". 192

Portanto, o jornal foi condenado ao pagamento do valor de $\mathrm{R} \$ 15 \mathrm{mil}$ a título de indenização por danos morais, tendo em vista tratar-se, de acordo com o desembargador relator, de "verdadeiro abuso do direito à informação que, sem dúvida nenhuma, gerou abalo psicológico" 193.

${ }^{191}$ TJ/RJ, Apelação Cível n 0101856-58.2007.8.19.0001, Rel. Desembargador Marcos Alcino de Azevedo Torres. Rio de Janeiro, 13 jul. 2010. (grifei)

${ }^{192}$ Ibid. (grifei)

${ }^{193}$ Ibid 


\section{CONCLUSÃo}

A relação de mútua desconfiança entre os meios de comunicação e o Poder Judiciário tem levado, como se viu, a erros de ambos os lados. Muitas decisões judiciais contra jornalistas e veículos de comunicação ferem a Constituição Federal na medida em que estabelecem uma forma de censura que não é por ela autorizada. A imprensa, por sua vez, condena decisões que obedecem à lei e à Constituição, criticando o Poder Judiciário e incitando contra ele o ódio da população, em grande parte das vezes, sem motivos para tanto.

Em meio a esse conflito, a maior prejudicada é a sociedade, que, de um lado, se vê privada do acesso às notícias e opiniões por erros cometidos pelo Judiciário e, de outro, recebe, da imprensa, informações sobre processos e decisões judiciais, muitas vezes, equivocadas ou imprecisas.

A leitura do $\$ 2^{\text {o194}^{194}}$ do artigo 220 da Constituição Federal dá a entender, a princípio, que toda e qualquer forma de censura das liberdades de expressão e imprensa seria inconstitucional. No entanto, caso se entenda, como se buscou demonstrar ao longo deste trabalho, que "censurar" é limitar, de qualquer forma, a livre expressão de ideias e opiniões, as restrições impostas pelo Poder Judiciário às notícias, seja antes ou depois da publicação dessas, também deverão ser entendidas como tal. Considerando que o $\S 1^{\circ}$ do mesmo dispositivo constitucional prevê as possíveis restrições à liberdade de informação jornalística, sendo uma delas aquela limitação prevista no inciso $\mathrm{X}$ do artigo $5^{\circ}$ da Carta Magna, pode-se concluir que o Poder Judiciário poderá limitar a livre expressão da imprensa sem ferir a Constituição, sempre que o exercício dessa liberdade conflitar com outros direitos fundamentais e que esses últimos prevalecerem no caso concreto.

\footnotetext{
${ }^{194} \S 2^{\circ}$ - "É vedada toda e qualquer censura de natureza política, ideológica e artística."
} 
Os direitos à honra, à intimidade, à vida privada e à imagem são direitos tão fundamentais quanto as liberdades de expressão e imprensa. $\mathrm{O}$ princípio da imparcialidade do juiz e também o resguardo do segredo de justiça são garantias constitucionais e legais da justiça das decisões tomadas pelo Poder Judiciário e, portanto, de suma importância para evitar que os julgamentos sejam arbitrários.

Em razão da importância das liberdades de expressão e imprensa para a existência de uma sociedade pluralista e, portanto, democrática, essas ocupam, como se mostrou acima, de acordo com parte da doutrina e com a jurisprudência do Supremo Tribunal Federal, posição de preferência quando do seu conflito com outros direitos fundamentais. Nas palavras do Ministro do STF CARlos Ayres Britto: “(...) a Constituição fez sua escolha (...) venceram os direitos de liberdade intelectual, de manifestação de pensamento, sobre os direitos da personalidade" ${ }^{195}$, o que não quer dizer, no entanto, que esses últimos não mereçam proteção.

Da posição de preferência das liberdades de expressão e imprensa resulta a absoluta excepcionalidade da proibição prévia de expressões, reservando-se essa medida aos raros casos em que a composição posterior do dano causado a outros direitos fundamentais possa ser impossível ou inviável.

Assim, conclui-se que o conflito entre as liberdades de imprensa e expressão com os direitos da personalidade, bem como com as garantias do segredo de justiça, da imparcialidade do juiz e da presunção de inocência, que, em última instância, visam assegurar esses direitos, deve ser resolvido, sempre que possível, após a publicação dos fatos, ideias e opiniões.

No entanto, o que se vê em muitas decisões judiciais, especialmente naquelas proferidas pelos juízes de primeira instância, não é a ponderação $a$

\footnotetext{
195 AGÊNCIA ESTADO. “Ayres Britto defende a liberdade à informação”. Estadão. São Paulo, 10 abr. 2010. Disponível em <http://www.estadao.com.br/noticias/nacional,ayres-britto-defendeliberdade-a-informacao,536520,0.htm>. Acesso em 20 out. 2010.
} 
posteriori entre tais liberdades, os direitos da personalidade e as garantias da justa decisão, mas sim, a censura prévia, que, deveria ser evitada, buscando que toda e qualquer expressão pudesse ser publicada ao menos uma vez.

Ainda que essas decisões sejam revertidas nas instâncias superiores do Poder Judiciário, tal reversão não é suficiente para apagar os estragos produzidos pela proibição prévia das expressões, já que até que sobrevenha a nova decisão em sentido contrário, a expressão estará cerceada e a população estará privada de conhecer o conteúdo das notícias ou críticas que seriam publicadas.

Deve-se, portanto, evitar, de qualquer maneira, a cesura prévia, pois, nas palavras do já citado Ministro AYRES BRITTO: "não cabe ao Estado, por qualquer dos seus órgãos, definir previamente o que pode ou o que não pode ser dito por indivíduos e jornalistas" 196.

Mesmo quando a censura prévia tiver como objetivo evitar que o segredo de justiça seja prejudicado, e com ele a imparcialidade das investigações e decisões judiciais, deve-se preferir a liberdade. $\mathrm{O}$ segredo de justiça parece de fato não ser destinado aos jornalistas, que poderão tratar do assunto investigado desde que obtenham informações sobre ele por outros meios que não impliquem na violação do sigilo. Como determina o Ministro do STF MARCO AURÉLIO MELLO deve-se combater o vazamento das informações sem chegar a prejudicar a liberdade de expressão ${ }^{197}$.

Ademais, nas condenações ulteriores, as indenizações têm sido muito elevadas, proporcionalmente ao tamanho do veículo condenado, colocando em risco a continuação de suas atividades. O Poder Judiciário tem, portanto,

\footnotetext{
${ }^{196}$ STF, ADPF 130, Rel. Ministro Carlos Britto. Brasília, 30 abr. 2009.

197 MACEDO, Fausto. "Vazamento é antecedente, não é erro do jornal", diz Marco Aurélio. O Estado de S. Paulo. São Paulo, 15 ago. 2009. Disponível em < http://www.estadao.com.br/estadaodehoje/20090815/not_imp419227,0.php>. Acesso em 13 set. 2010.
} 
errado na imposição da censura prévia e exagerado nas condenações $a$ posteriori.

No entanto, embora haja certo exagero nas condenações a posteriori das publicações, a censura ulterior, é, sim, necessária em alguns casos, para que seja feita a reparação da ofensa a outros direitos no exercício da livre expressão.

As pesadas críticas ao Poder Judiciário e aos juízes, por outro lado, em que pese o dever dos jornalistas de fiscalizar e denunciar as mazelas dos Poderes Públicos, muitas vezes não se justificam ou são exageradas. Afinal, ainda que não se entenda por justas, as decisões criticadas são, em grande parte das vezes, legais e constitucionais.

Não se trata aqui de incentivar a autocensura, já que essa é, como visto, a pior forma de restrição da expressão e a mais difícil de se combater, mas é preciso que jornalistas e meios de comunicação procurem entender melhor as decisões proferidas pelo Poder Judiciário antes de criticá-las.

É preciso também, no entanto, que os juízes, em especial os de primeira instância, tenham maior cuidado no trato das liberdades de expressão e imprensa e que levem em consideração o valor que elas têm para uma sociedade democrática, deixando para reparar eventuais excessos no seu exercício, se possível, depois de cometidos. Na dúvida, portanto, a liberdade deve prevalecer. 


\section{BIBLIOGRAFIA}

AGÊNCIA ESTADO. "Ayres Britto defende a liberdade à informação". Estadão. São Paulo, 10 abr. 2010. Disponível em <http://www.estadao.com.br/noticias/nacional,ayres-britto-defendeliberdade-a-informacao,536520,0.htm>. Acesso em 20 out. 2010.

ALEXY, Robert. Teoria de los derechos fundamentales. Tradução: Ernesto Garzón Valdés. Madrid: Centro de Estúdios Políticos y Constitucionales, 2002. p. $90-100$.

AMARAL, Roberto. Imprensa e Controle da Opinião Pública: Informação e Representação no Mundo Globalizado. Disponível em < http://www.rblinux.com.br/rogeriobarreto/mesuneb/Roberto_Amarval.pdf>. Acesso em 10 out. 2010. p. 130-153.

ANDRADE, Fábio Martins de. Mídia e Poder Judiciário: A influência dos órgãos da mídia no processo penal brasileiro. Rio de Janeiro: Lúmen Júris, 2007. $445 \mathrm{p}$.

ARAGÃO, Egas Dirceu Moniz de. Comentários ao Código de Processo Civil. v. II. Rio de Janeiro: Forense, 1998. p.10-20.

ASSEJO, Henrique J. Concepcion Técnico Jurídica de La Instruccion Criminal. In: Revista de Derecho Procesal no 4. p. 87-876.

Associação Nacional de Jornais. Relatório sobre liberdade de imprensa no Brasil. Disponível em <http://www.anj.org.br/programas-eacoes/relatorios/relatorios-de-liberdade-deimprensa/copy_of_rellibim2004_2006.pdf >. Acesso em 10 out. 2010. 18 p.

BALEEIRO, Aliomar. Constituições Brasileiras: 1891. $2^{\mathrm{a}}$ ed. Brasília: Senado Federal; Ministério da Ciência e Tecnologia, Centro de Estudos Estratégicos, 2001. p.77-107.

Constituições Brasileiras: 1946. $2^{\mathrm{a}}$ ed. Brasília: Senado Federal; Ministério da Ciência e Tecnologia, Centro de Estudos Estratégicos, 2001. p.63-121.

; BRITO, Luiz Navarro de. Constituições Brasileiras:

1967. $2^{\mathrm{a}}$ ed. Brasília: Senado Federal; Ministério da Ciência e Tecnologia, Centro de Estudos Estratégicos, 2001. P.93-183. 
BARROSO, Luis Roberto. Colisão entre Liberdade de Expressão $e$ Direitos da Personalidade. Critérios de Ponderação: Interpretação Constitucionalmente adequada do Código Civil e da Lei de Imprensa. Artigo disponível em <http://www.migalhas.com.br/arquivo_artigo/art_0310-01.htm>. Acesso em 15 set. 2010.

- Liberdade de expressão, censura e controle da programação de televisão na Constituição de 1988. In: Temas de direito constitucional, t.I, $2^{\mathrm{a}}$ ed. Rio de Janeiro: Renovar, 2001. p.341 - 387.

BASTOS, Celso Ribeiro. Curso de Direito Constitucional. $11^{\mathrm{a}}$ ed. São Paulo: Saraiva, 1989. p.36-43.

BELlUSCIO, Augusto César. La Censura Judicial. In: Anuário de Derecho Constitucional Latinoamericano, 2006. p.949-963.

BERTONI, Eduardo Andrés. Liberdad de expresión em el Estado de derecho: doctrina e jurisprudencia nacional, extranjera e internacional. $2^{\mathrm{a}}$ ed. Ciudad Autónoma de Buenos Aires: Del Puerto, 2007. p.83-108.

BITELLI, Marcos Alberto Sant'anna. O Direito da Comunicação e da Comunicação Social. São Paulo: Editora Revista dos Tribunais, 2004. p.189-235.

BOHÈRE, G. Profissão: Jornalista: um estudo dos jornalistas como trabalhadores. Tradução: Dario Luis Borelli. São Paulo: LTr, 1994. p.103113.

BUDÓ, Marília Denardin. O jornalismo e os julgamentos: uma abordagem acerca da possibilidade de influência da mídia em decisões judiciais. Disponível em <http://www.intercom.org.br/papers/nacionais/2005/resumos/R1213-1.pdf >. Acesso em 22 set. 2010. 15 p.

BUENO, Cássio Scarpinella. Curso Sistematizado de Direito Processual Civil: Teoria Geral do Direito Processual Civil. v. 1. São Paulo: Saraiva, 2007. p.114-132.

CADERNO BRASIL. "Jornal terá que pagar R \$ 593 mil para juiz". Folha de São Paulo, São Paulo, p. A10, 26 jun. 2009.

CALDAS, Pedro Frederico. Vida privada, liberdade de imprensa e dano moral. $2^{a}$ ed. São Paulo: Saraiva, 1997. p.60-64. 
CANOTILHO, José Joaquim Gomes; MOREIRA, Vital. Constituição da República Portuguesa. São Paulo: Editora Revista dos Tribunais, 2007. p.235-242.

CARVALHO, Luís Gustavo Grandinetti Castanho de. Direito de informação e liberdade de expressão. Rio de Janeiro: Renovar, 1999. p.1730.

Informação e o Direito difuso à informação verdadeira. Rio de Janeiro: Renovar, 1994. 98 p.

CHUEIRI, et al. Segredo de Justiça: Aspectos processuais controvertidos e liberdade de imprensa. Disponível em <http://www.fafibe.br/revistasonline/arquivos/revistajuridicafafibe/sumario/ 5/14042010170941.pdf>. Acesso em 05 out. 2010.20 p.

DALLARI, Dalmo de Abreu. Estadão, censura e autocensura. Disponível em

<http://www.observatoriodaimprensa.com.br/artigos.asp?cod=559JDB007> . Acesso em 15 out. 2010.

DOMINGUEZ, Daniela Montenegro Mota. A influência da Mídia nas decisões do Juiz penal. Disponível em $\langle$ http://www.revistas.unifacs.br/index.php/redu/article/view/507〉. Acesso em 02 out. 2010.

FAGUNDES, Coriolano de Loyola Cabral. Censura \& liberdade de expressão. São Paulo: Editora Edital e Distribuidora Record, 1974. p.289403.

FARIAS, Edilsom Pereira de. Colisão de direitos: a honra, a intimidade e a imagem versus a liberdade de expressão e informação. Porto Alegre: Sérgio Antonio de Fabris, 2000. p.150-168.

- Democracia, censura e liberdade de expressão e informação na Constituição Federal de 1988. Disponível em < http://jus2.uol.com.br/doutrina/texto.asp?id=2195>. Acesso em 11 out. 2010.

Liberdade de Expressão e Comunicação, teoria e proteção constitucional. São Paulo: Editora Revista dos Tribunais, 2004. p.52-189. 
FAUNDES, Juan Jorge. Ética y contexto Del periodismo de investigación. Sala de Prensa - Web para professionales de la comunicación iberoamericanos, ano IV, v. 2, $\mathrm{n}^{\mathrm{o}} 43,2002$. Disponível em <www.saladeprensa.org/art274.htm>. Acesso em 01 out. 2010.

FERREIRA, Aurélio Buarque de Holanda. Coordenado por Margarida dos Anjos e Marina Baird Ferreira. Míni Aurélio: O dicionário da língua portuguesa. $6^{a}$ ed. Curitiba: Positivo, 2005. p.244.

FERREIRA, Manuel Alceu Affonso. Censura Legislada. In: Revista do Advogado. Ano XXX. no 109, ago. 2010. Associação dos Advogados de São Paulo. p.76-80.

FGV. CPDOC. Diretrizes do Estado Novo (1937-1945): Departamento de Imprensa e Propaganda. Disponível em <www.cpdoc.fgv.gov.br>. Acesso em 06 set. 2010.

FISS, M. Owen. A Ironia da Liberdade de Expressão: Estado, Regulação e Diversidade na Esfera Pública. Tradução e Prefácio de Gustavo Binebojm e Caio Mário da Silva Pereira Neto. Rio de Janeiro: Renovar, 2005. p.01-99.

El Efecto Silenciodor de La liberdad de expressión. In. Isonomia, Revista de Teoria y Filosofia Del Derecho, n. 4, abr. 1996. Disponível em http://www.cervantesvirtual.com/servlet/SirveObras/014740633226363842 54480/isonomia04/iso03.pdf>. Acesso em 25 set. 2010.

HABERMAS, Jürgen. Mudança Estrutural da Esfera Pública: Investigações quanto a uma categoria da sociedade burguesa. Tradução: Flávio R. Kothe. Rio de Janeiro: Tempo Brasileiro, 1984. p.283-287.

JABUR, Gilberto Haddad. Liberdade de Pensamento e Direito à Vida Privada: conflitos entre direitos da personalidade. São Paulo: Editora Revista dos Tribunais, 2000. p.164-165.

JÚNIOR, José Cretella. Comentários à Constituição de 1988. v.1. Rio de Janeiro: Forense, 1992. p.250-256.

JÚNIOR, Vidal Serrano Nunes. A Proteção Constitucional da Informação e $o$ Direito à Crítica Jornalística. Coordenação: Hélio Bicudo. São Paulo: FTD, 1997. 135 p.

LEYSER, Maria Fátima Vaqueiro Ramalho. Direito à Liberdade de Imprensa. São Paulo: J. de Oliveira, 1999. p.49-81. 
LIPPMANN, Walter. Opinião Pública. Tradução e prefácio: Jacques A. Wainberg. Coleção Clássicos da Comunicação Social. Petrópolis: Editora Vozes, 2008. p.271-311.

MACEDO, Fausto. "Vazamento é antecedente, não é erro do jornal", diz Marco Aurélio. O Estado de S. Paulo. São Paulo, 15 ago. 2009. Disponível em<http://www.estadao.com.br/estadaodehoje/20090815/not_imp419227,0. php>. Acesso em 13 set. 2010.

MACHADO, Jonatas E. M. Liberdade de Expressão. Coimbra: Almedina, 2002. p.564-568.

MARTINO, Aguinaldo; SAPATERRA, Ana Paula. A Censura no Brasil do Século XVI ao Século XIX. In: Estudos Lingüísticos XXXV, 2006. 234-243 p. Disponível em <http://www.usp.br/proin/download/artigo/artigos_censura_brasil.pdf $>$. Acesso em 05 set. 2010.

MARX, Karl. Liberdade de Imprensa. Tradução: Cláudia Schilling e José Fonseca. Porto Alegre: L\&PM, 2010. p.91-108.

NASSIF, Luis. $O$ segredo de justiça. Disponível em <http://luisnassifonline.blog.uol.com.br/>. Acesso em 10 out. 2010.

NAVES, Nelson Vital. Relações entre a Imprensa e a Justiça no Brasil. Disponível em <http://bdjur.stj.gov.br>. Acesso em 10 set. 2010. 6p.

NETO, Guilherme Fernandes. Direito da Comunicação Social. São Paulo: Editora Revista dos Tribunais, 2004. p.78- 100.

NOGUEIRA, Octaciano. Constituições Brasileiras: 1824. 2a ed. Brasília: Senado Federal; Ministério da Ciência e Tecnologia, Centro de Estudos Estratégicos, 2001. p.79-107.

NORONHA, Joanna; SANTANA, Carolina. Jürgen Habermas: Ética Discursiva e Sujeito Deliberativo. 07 p.

"Operação Navalha: TJ/DF absolve jornalista acusado pelos crimes de calúnia, injúria e difamação". Disponível em $<$ http://www.correioforense.com.br/noticia/idnoticia/58212/titulo/TJDF_ab solve_jornalista_acusado_pelos_crimes_de_calunia_injuria_e_difamacao.ht ml>.Acesso em 02 de out. 2010. 
PAIVA, Anabela; RAMOS, Silvia. Mídia e Violência: Tendências na cobertura de criminalidade e segurança no Brasil. Rio de Janeiro: Iuperj, 2007. p.77-86.

POLETTI, Ronaldo. Constituições Brasileiras: 1934. $2^{\mathrm{a}}$ ed. Brasília: Senado Federal; Ministério da Ciência e Tecnologia, Centro de Estudos Estratégicos, 2001. p.150-158.

PORTO, Walter Costa. Constituições Brasileiras: 1937. $2^{\mathrm{a}}$ ed. Brasília: Senado Federal; Ministério da Ciência e Tecnologia, Centro de Estudos Estratégicos, 2001. p.44-45.

REZENDE, Jorge. Segredo de Justiça, liberdade de imprensa e moralidade. Disponível em < http://www.paraibanews.com/2008/04/07/segredo-dejustica-liberdade-de-imprensa-e-moralidade/>. Acesso em 30 set. 2010.

RODRIGUES, J.N. Cunha. Justiça e Comunicação Social. In: Revista portuguesa de ciência criminal. A.7, nº (Out.-Dez. 1997). p.560-565.

SAGÜES, Néstor Pedro. Censura judicial previa a la prensa: Posición de La Corte Interamericana de Derechos Humanos. In: Anuário de Derecho Constitucional Latinoamericano, 2006. p.965-975.

SANTOS, Reinaldo. A Ética na Comunicação (Textos dos Códigos). $2^{\mathrm{a}}$ ed. Rio de Janeiro: Destaque, 1996. p.4-10.

SCHREIBER, Simone. Liberdade de Expressão: Justificativa Teórica e a Doutrina da Posição Preferencial no Ordenamento Jurídico. In: BARROSO, Luis Roberto (Org.). A Reconstrução democrática do direito público no Brasil. São Paulo: Renovar, 2007. p.229.

SERRÃO, Osvaldo. Segurança Pública, Imprensa e Direitos Individuais. Boletim do IBCCrim. São Paulo, nº 57, ago. 1997. p.08-10.

SILVA, Carlos Eduardo Lins. Censura Judicial à Imprensa no Brasil: Autorregulação e maturidade democrática. In: Ensaios do Instituto de Estudos Econômicos e Internacionais (UNESP). São Paulo, 2010. Disponível em <http://www.ieei-unesp.com.br>. Acesso em 01 set. 2010. $27 \mathrm{p}$.

SILVA, José Afonso da. Curso de Direito Constitucional Positivo. $28^{\mathrm{a}}$ ed. São Paulo: Malheiros, 2007. p.243-248. 
SKIDMORE, Thomas E. Brasil: de Getúlio Vargas a Castelo Branco, 19301964. Tradução coordenada por Ismênia Tunes Dantas. $7^{\text {a }}$ ed. Rio de Janeiro: Paz e Terra, 1982. p.21-64.

. Brasil: de Castelo a Tancredo. Tradução: Mário

Salviano Silva. $7^{a}$ ed. Rio de Janeiro: Paz e Terra, 1988. p.101-110.

SORIANO, Ramon. Las Libertades Públicas. Madri: Techonos, 1999. p. 140-144.

TAVARES, André Ramos, p. 551 Apud MAYER-PFLUG, Samantha Ribeiro. Liberdade de Expressão e Discurso do Ódio. São Paulo: Editora Revista dos Tribunais, 2010. p.272.

TOCQUEVILLE, Alexis de. A Democracia na América: Livro II, Sentimentos e Opiniões. Tradução: Eduardo Brandão. São Paulo: Martins Fontes, 2004. p.113-195.

TOLLER, Fernando M. O Formalismo da Liberdade de Expressão. São Paulo: Saraiva, 2010. 118 p.

VIDGAL, Edson Carvalho. Censura da Imprensa pelo Poder Judiciário. Disponível em

http://bdjur.stj.gov.br/xmlui/bitstream/handle/2011/255/Censura_da_Impre nsa.pdf?sequence=1>. Acesso em 15 out. 2010. 16 p.

\section{Jurisprudência}

$12^{\mathrm{a}}$ Vara Cível do Distrito Federal, Ação Inibitória com pedido liminar $\mathrm{n}^{\mathrm{o}}$ 2009011113988-3, Juiz Daniel Felipe Machado. Brasília, 27 jul. 2009.

$22^{\mathrm{a}}$ Vara Cível do Rio de Janeiro, Processo ${ }^{0}$ 0101856-58.2007.8.19.0001, Juíza Tânia Paim Caldas de Abreu. Rio de Janeiro, 02 set. 2009.

$2^{\mathrm{a}}$ Vara Cível de São Paulo. Processo $\mathrm{n}^{\mathrm{o}}$ 011.06.119805-8. Juíza Luciana Novakoski Ferreira Alves de Oliveira. São Paulo, 17 set. 2010.

$3^{a}$ Vara Cível de Teresina, Ação de Reparação de Danos Morais $\mathrm{n}^{\circ}$ 1020159197, Juiz Antônio Peres Parente. Teresina, $1^{\circ}$ fev. 2001.

$4^{\mathrm{a}}$ Vara Cível de Pinheiros, Processo $\mathrm{n}^{\mathrm{o}}$ 011.02.001.112-2 e 011.01.021.146-3, Juiz Carlos Roberto Petroni. São Paulo, 14 ago. 2003. 
$33^{\mathrm{a}}$ Vara Cível de São Paulo, Processo $n^{\circ}$ 000.99.063777-8. Juíza Vivian Wiptli Zanelli. São Paulo, 27 mai. 2001.

$51^{\text {a }}$ Vara Cível do Rio de Janeiro, Processo 0089353-97.2010.8.19.0001, Juiz Alessandro Oliveira Felix. Rio de Janeiro, 09 ago. 2010.

$5^{\text {a }}$ Vara Cível de São José dos Campos. Processo no 577.09.406140-9. Juíza Ana Paula Theodosio de Carvalho. São José dos Campos, 21 set. 2010.

Comarca de São Lourenço do Sul, Processo n ${ }^{\circ}$ 067/1.03.0001565-2, Juiz Diego Leonardo Di Marco Piñeiro. São Lourenço do Sul, 12 ago. 2003.

STF, ADPF 130, Rel. Ministro Carlos Britto. Brasília, 30 abr. 2009.

STF, HC 83728/RS. Rel. Ministro Marco Aurélio. Brasília, 17 fev. 2004.

STF, Pet. 3486/DF, Rel. Ministro Celso de Mello. Brasília, 22 ago. 2005.

STF, Reclamação 9428/DF, Rel. Ministro Cezar Peluso. Brasília, 10 dez. 2009.

STJ, RMS n 3292-PR, Rel. Ministro Costa Leite. Brasília, 04 abr.1995.

STJ, RMS n 398-MG, Rel. Ministro Fontes Alencar. Brasília, 16 mar. 1992 - DU 03.08.1992.

STJ. Resp 984.803. Rel. Ministra Nancy Andrighi. Brasília, 26 mai. 2009.

Procedimento de Investigação Criminal do inquérito 2007.37.00.00017524.

TJ/CE, $3^{\text {a }}$ Câmara Cível, Apelação Cível no 55590236200080600011 , Rel. Desembargadora Edite Bringel Olinda Alencar. Fortaleza, 04 ago. 2007.

TJ/DF, Agravo de Instrumento ${ }^{\circ}$ 2009002010738-6, Rel. Desembargador Dácio Vieira. Brasília, 31 jul. 2009.

TJ/DF, Mandado de Segurança $\mathrm{n}^{\circ}$ 200900211261-7, Rel. Desembargador Waldir Leôncio Junior. Brasília, 13 ago. 2009.

TJ/DF, Ofício GPR $n^{\circ}$ 009/GD/2009 em Mandado de Segurança ${ }^{\circ}$ 200900211261-7, Rel. Ministro Waldir Leôncio Junior. Brasília, 18 ago. 2009. 
TJ/PI, $3^{\text {a }}$ Câmara Cível, Agravo de Instrumento $n^{\circ}$ 01.000195-6, Rel. Desembargador Francisco Landim. Teresina, $1^{\circ}$ dez. 2009.

TJ/RJ, Apelação Cível $\mathrm{n}^{\circ}$ 0052955-84.2006.8.19.0004, Rel. Desembargadora Maria Regina Nova. Rio de Janeiro, 18 ago. 2010.

TJ/RJ, Apelação Cível no 0101856-58.2007.8.19.0001, Rel. Desembargador Marcos Alcino de Azevedo Torres. Rio de Janeiro, 13 jul. 2010.

TJRS, Apelação Cível no 70007346398, Rel. Desembargador Adão Sérgio do Nascimento Cassiano. Porto Alegre, 22 mar. 2006.

TJ/SP, Apelação Cível com Revisão no 226.995-4/2-00, Rel. Desembargador André Augusto Salvador Bezerra. São Paulo, 19 out. 2005.

TRE/TO, Representação $n^{\circ}$ 1.594-44.2010.6.27.0000, Rel. Desembargador Liberato Povoa. Palmas, 24 set. 2010. 
A presente Monografia, apresentada pela aluna PAULA STRUNCK DA SILVA PINTO, poderá ser submetida à exposição e defesa perante a Banca Examinadora designada pelo Departamento de Direito da PUC-Rio.

Rio de Janeiro, de de 2010.

Fábio Carvalho Leite

Assinatura do professor orientador

A autora deste trabalho autoriza o Departamento de Direito da PUCRio a divulgá-lo, no todo ou em parte, resguardados os direitos autorais conforme legislação vigente.

Rio de Janeiro, de 2010.

Assinatura da aluna 